University at Buffalo School of Law

Digital Commons @ University at Buffalo School of Law

\title{
Federal Habeas Corpus and the Mapp Exclusionary Rule After Stone v. Powell
}

Philip Halpern

University at Buffalo School of Law

Follow this and additional works at: https://digitalcommons.law.buffalo.edu/journal_articles

Part of the Criminal Procedure Commons, and the Evidence Commons

\section{Recommended Citation}

Philip Halpern, Federal Habeas Corpus and the Mapp Exclusionary Rule After Stone v. Powell, 82 Colum. L. Rev. 1 (1982).

Available at: https://digitalcommons.law.buffalo.edu/journal_articles/103

This article originally appeared at 82 Colum. L. Rev. 1 (1982). Reprinted by permission.

\section{C. ${ }_{\text {COPYRIGHT }}^{\text {N }}$}

This Article is brought to you for free and open access by the Faculty Scholarship at Digital Commons @ University at Buffalo School of Law. It has been accepted for inclusion in Journal Articles by an authorized administrator of Digital Commons @ University at Buffalo School of Law. For more information, please contact lawscholar@buffalo.edu. 


\title{
COLUMBIA LAW
}

REVIEW

VOL. 82

JANUARY 1982

NO. 1

\section{Federal Habeas Corpus and the Mapp Exclusionary Rule After Stone v. Powell}

\author{
Philip Halpern*
}

In Stone v. Powell ${ }^{1}$ the Supreme Court severely limited litigation of fourth amendment claims by state prisoners in federal habeas corpus proceedings. Specifically, Stone held that convictions obtained by use of evidence procured through a violation of the fourth amendment are not ordinarily open to attack on habeas corpus. There was an exception, however: habeas review would be available where the state had not provided a defendant with an "opportunity for full and fair litigation" of a search and seizure claim. ${ }^{2}$ The Court did not elaborate on the content of the qualification and, more basically, did not set forth a theoretical justification. Absent such guidance or justification, lower federal courts have encountered formidable difficulties in defining the permissible limits of collateral review of fourth amendment exclusionary rule claims under the exception. ${ }^{3}$

It has been said of Stone that its significance extends well beyond fourth amendment habeas corpus litigation, that it is a "harbinger of future eviscerations" 4 of habeas corpus jurisdiction over constitutional claims unrelated to

*Associate Professor of Law, State University of New York at Buffalo, B.A. 1968, Columbia College; J.D. 1973, University of Pennsylvania.

I would like to thank Lee Albert and AI Katz of the State University of New York for their comments on an earlier draft of this Article.

1. 428 U.S. 465 (1976).

2. Id. at 482,494 .

3. See Mincey v. Arizona, 437 U.S. 385 (1978), where Justice Marshall remarked in his concurrence: "The Stone holding has not eased the burden on the lower federal courts as much as the Stone majority might have hoped, since those courts have had to struggle over what this court meant by 'an opportunity for full and fair litigation of a Fourth Amendment claim' . . . ." Id. at 404 n.2 (Marshall, J., concurring).

4. 428 U.S. at 516 (Brennan, J., dissenting). Justice Brennan, in a bitter dissent, accused the majority of having rewritten the habeas corpus statutes to deny federal collateral relief for constitutional violations that are unrelated to the reliability of the factfinding process.

[T]he real ground for today's decision-a ground that is particularly troubling in

light of its portent for habeas jurisdiction generally-is the Court's novel reinterpretation of the habeas statutes; this would read the statutes as requiring the district courts routinely to deny habeas relief to prisoners "in custody in violation of the Constitution or laws ... of the United States" as a matter of judicial "discretion" . . because such claims are "different in kind" from other constitutional violations in that they "do not 'impugn the integrity of the fact-finding process," " . . . and because application of such constitutional strictures "often frees the guilty." ... Much in the Court's opinion suggests that a construction of the habeas statutes to deny relief for non-"guilt-related" constitutional violations, based on this Court's vague notions of comity and federalism 
the integrity of the guilt-determination process, and, moreover, that the reasoning of the decision logically dictates complete abandonment of the exclusionary rule. ${ }^{5}$ Contrary to these expectations, however, there has been no general curtailment of habeas corpus jurisdiction over constitutional claims unrelated to the reliability of the fact-finding process, ${ }^{6}$ and the exclusionary rule has remained substantially intact since Stone was decided in $1976 .^{7}$

Building on the reasoning and logic of Stone, this Article seeks to develop a theoretical justification in support of a system of limited federal habeas corpus review of fourth amendment exclusionary rule claims, and to define the conditions under which such review should occur. Additionally, the Article considers the implications of Stone for continued enforcement of the exclusionary rule and for federal collateral review of non-fourth amendment claims.

Part I examines the legal and factual propositions considered in Stone, which provide the framework for understanding the exception as well as the decision's other implications. Part II discusses and criticizes various under-

$\ldots$ is the actual premise for today's decision . . . . For we are told that "[r]esort to habeas corpus, especially for purposes other than to assure that no innocent person suffers an unconstitutional loss of liberty, results in serious intrusions on values important to our system of government." ... We are told that federal determination of Fourth Amendment claims merely involves "an issue that has no bearing on the basic justice of [the defendant's] incarceration." ... and that "the ultimate question [in the criminal process should invariably be] guilt or innocence."

Id. at 515-17 (citations to the majority opinion omitted).

Some commentators share this view of the Stone majority opinion. See, e.g., Cover \& Aleinikoff, Dialectical Federalism: Habeas Corpus and the Court, 86 Yale L.J. 1035, 1086-87 (1977). But see Seidman, Factual Guilt and the Burger Court: An Examination of Continuity and Change in Criminal Procedure, 80 Colum. L. Rev. 436, 450-59 (1980).

5. Chief Justice Burger, concurring in Stone, observed a need for "overruling this judicially contrived doctrine-or limiting its scope to egregious, bad-faith conduct." 428 U.S. at 501 (Burger, C.J., concurring). He characterized the majority's statement that expressed continued adherence to implementing the exclusionary rule at trial and on appeal, id. at 492 , as coming "[b]y way of dictum, and somewhat hesitantly." Id. at 496 (Burger, C.J., concurring).

6. See Rose v. Mitchell, 443 U.S. 545 (1979) (refusing to extend Stone's holding to a grand jury discrimination claim).

7. This is not to say, however, that the exclusionary rule has flourished under the Burger Court. Prior to Stone, United States v. Calandra, 414 U.S. 338 (1974), ruled that a witness could not object to grand jury questioning based on information obtained through a fourth amendment violation. In addition, the Court has maintained its unwillingness to extend the exclusionary rule beyond the confines of the criminal trial. For example, United States v. Janis, 428 U.S. 433 (1976), decided the same day as Stone, held that the exclusionary rule did not apply to an I.R.S. civil assessment proceeding where local police had engaged in an illegal search. Also, in postStone decisions, the Court has declined to extend the fruit of the poisonous tree doctrine to the testimony of a witness, United States v. Ceccolini, 435 U.S. 268 (1978); refused to suppress evidence obtained in a search pursuant to an arrest in good faith under a "presumptively valid" statute when the statute is subsequently declared unconstitutional, Michigan v. DeFillippo, 443 U.S. 31 (1979); permitted the Government to use illegally obtained, and otherwise inadmissible, evidence to impeach a defendant's responses to cross-examination, United States v. Havens, 446 U.S. 620 (1980); and held that the federal courts may not invoke their supervisory power over federal law enforcement to exclude evidence obtained in violation of the fourth amendment rights of third parties other than the defendants before them, United States v. Payner, 447 U.S. 727 (1980). The fact remains, however, that it is still the law that state and federal prosecutors may not use evidence obtained as a direct result of a violation of a defendant's fourth amendment rights as part of the case in chief against him. 
standings of the exception by the lower federal courts. Part III explicates a theory to explain Stone's ban on fourth amendment habeas litigation and the exception thereto. Part IV proposes a standard for determining the availability of collateral review under Stone. Part V considers Stone's significance in areas beyond fourth amendment habeas litigation.

\section{STONE V. POWELL}

\section{A. The Decisions}

Stone v. Powell ${ }^{8}$ and Wolff $v$. Rice ${ }^{9}$ were companion cases in the Supreme Court. The respondent in Stone, Lloyd Powell, was convicted of second-degree murder in a California court as a result of a homicide committed during an attempted holdup of a liquor store. The prosecution introduced into evidence a revolver, said to be the murder weapon, which was found in Powell's possession ten hours after the homicide when he was searched incident to his arrest in Henderson, Nevada, for violation of a local vagrancy ordinance. The state courts rejected Powell's contention that the vagrancy ordinance was unconstitutionally vague, and that, therefore, the revolver and the testimony of a Henderson police officer concerning its discovery should be suppressed as fruits of an unconstitutional arrest. ${ }^{10}$ Subsequently, the federal district court denied the respondent's request for habeas corpus relief. The court gave two reasons for this denial: first, that the deterrent purpose of the exclusionary rule would not be served by suppressing the fruits of an otherwise valid arrest under an unconstitutional statute; and, second, that the error, if any, was harmless. ${ }^{11}$ The Court of Appeals for the Ninth Circuit reversed. ${ }^{12}$ While conceding that exclusion would not deter police officers from making an arrest in good faith pursuant to an unconstitutional statute, the appellate court maintained that legislatures should be deterred from enacting unconstitutional statutes.

The respondent in Wolff, David Rice, was convicted in a Nebraska state court of first-degree murder in connection with the bombing death of an Omaha police officer. At his trial, the prosecution introduced into evidence dynamite, blasting caps, and other materials that had been used in the construction of explosive devices and had been found in a search of Rice's home. Rice sought to have this evidence excluded, contending that the warrant authorizing the search was invalid because of an insufficient suporting affidavit. The Nebraska trial court denied his motion to suppress, and the Nebraska Supreme Court affirmed. ${ }^{13}$ The district court granted Rice's petition for

8. 428 U.S. 465 (1976). Circuit.

9. Id. The cases were consolidated on certiorari to the Court of Appeals for the Eighth

10. The trial court was the only state court to reach the merits. The California court of appeal affirmed on the ground of harmless error, and the California Supreme Court denied review. 428 U.S. at 470.

11. Id. at $470-71$.

12. Powell v. Stone, 507 F.2d 93 (9th Cir. 1974).

13. State v. Rice, 188 Neb. 728, 199 N.W.2d 480 (1972). 
habeas corpus, having found that the warrant indeed was invalid. ${ }^{14}$ The Court of Appeals for the Eighth Circuit affirmed. ${ }^{15}$

The Supreme Court reversed the grant of habeas corpus relief in both cases, and held that

where the State has provided an opportunity for full and fair litigation of a Fourth Amendment claim, the Constitution does not require that a state prisoner be granted federal habeas corpus relief on the ground that the evidence obtained in an unconstitutional search and seizure was introduced at his trial. ${ }^{16}$

The federal habeas corpus statute mandates relief to state prisoners held "in custody in violation of the Constitution." 17 According to the Court, a person convicted on the basis of illegally seized evidence is not held in unconstitutional custody, because the exclusionary rule is not founded on a personal constitutional right of the accused. Instead, it is a judge-made remedial measure designed to deter the police from engaging in unconstitutional searches and seizures. ${ }^{18}$ Consequently, the Court stated, a determination of the availability of habeas corpus relief for search and seizure claims necessitates a balancing of the incremental deterrent benefits attainable from providing such relief against the attendant social costs. ${ }^{19}$ Concluding that the costs of federal habeas relief would outweigh its benefits, the Court banned habeas corpus consideration of fourth amendment claims except where the state did not provide "an opportunity for full and fair litigation." 20

The Court divided 6-3 in four opinions. ${ }^{21}$ The majority, despite its holding, explicitly reaffirmed continued adherence to compulsory state application of the exclusionary rule at trial and on appeal. ${ }^{22}$ The Chief Justice, in a concurrence, advocated the rule's total repudiation for lack of proof that

14. Rice v. Wolff, 388 F. Supp. 185 (D. Neb. 1974).

15. 513 F.2d 1280 (8th Cir. 1975).

16. 428 U.S. at 482 . The grants of certiorari, 428 U.S. at $474 \mathrm{n} .5$, appeared to invite arguments regarding the appropriateness or necessity of exclusion in these cases in light of their particular facts. Indeed, the principal arguments in petitioners' briefs to the Supreme Court were that the exclusionary rule should not apply because the police acted in good faith. Brief for Wolff petitioner at 9, 21-35; Brief for Stone petitioner at 2, 11-39. In Stone the police relied on a presumptively valid ordinance and in Wolff on a presumptively valid search warrant. The fault, if any, in Stone was that of the legislature in enacting an unconstitutional statute, and in Wolff was that of the magistrate in issuing a search warrant on the basis of a defective affidavit. Subsequently, in Michigan v. DeFillippo. 443 U.S. 31 (1979), the Court held that a search incident to an arrest made in good faith reliance on a statute later declared unconstitutional is not invalidated by the subsequent declaration of unconstitutionality.

17. 28 U.S.C. \$ 2254(a) (1976).

18. 428 U.S. at $486-89$.

19. Id. at 488 .

20. Id. at $482,494$.

21. Justice Powell authored the majority opinion, which was joined by Chief Justice Burger, and Justices Stewart, Blackmun, Rehnquist, and Stevens. The Chief Justice wrote a separate concurring opinion. Justice Brennan, joined by Justice Marshall, wrote a dissenting opinion, as did Justice White.

22. 428 U.S. at 493. 
exclusion actually deters official misconduct. ${ }^{23}$ Justice Brennan, in a vehement dissent, charged the majority with having usurped Congress's power to define the scope of habeas corpus jurisdiction. ${ }^{24}$ Justice White's dissent urged that the remedy should be available on collateral review, so long as state defendants are constitutionally entitled to invoke the exclusionary remedy for fourth amendment violations at trial and on appeal. ${ }^{25}$ Justice White, however, would not apply the exclusionary rule where the police have acted reasonably and in good faith. ${ }^{26}$

\section{B. The Legal Predicate}

The legal predicate for the Court's cost-benefit analysis is that the exclusionary rule is not a personal constitutional right, but rather a remedial device designed primarily to deter police violations of the fourth amendment. ${ }^{27}$ The majority recognized that the "imperative of judicial integrity" has been often mentioned in justification of exclusion. ${ }^{28}$ This rationale, however, did not figure independently into the Court's analysis, because judicial integrity is not offended merely by the admission of unlawfully seized evidence. Rather, the offense occurs when such admission provides an incentive for the police to engage in unconstitutional conduct. Consequently, judicial integrity analysis differs little from deterrence analysis. ${ }^{29}$

Deterrence, however, was not always the linchpin for exclusion of illegally seized evidence. In 1914 the Court unanimously adopted an exclusionary rule for federal proceedings in Weeks $v$. United States ${ }^{30}$ without mentioning

23. Id. at 496-502 (Burger, C.J., concurring).

24. Id. at 515-17 (Brennan, J., dissenting).

25. Id. at 536-42 (White, J., dissenting).

26. Id. at 538 (White, J., dissenting).

27. Id. at 486.

28. See 428 U.S. at $484-85$, and accompanying citations.

29. Id. at 485 . Justice Blackmun, writing for the Court in United States v. Janis, 428 U.S. 433 (1976), described the collapse of judicial integrity into deterrence:

The primary meaning of "judicial integrity" in the context of evidentiary rules is that the courts must not commit or encourage violations of the Constitution .... The focus ... must be on the question whether the admission of the evidence encourages violations of Fourth Amendment rights .... [T]his inquiry is essentially the same as the inquiry into whether exclusion would serve a deterrent purpose.

Id. at 458 n.35. But see United States v. Payner, 447 U.S. 727, 735 n.8 (1980) (exclusionary rule serves "'two-fold" purpose of deterring illegality and protecting judicial integrity").

The identification of the judicial integrity rationale with the instrumentalist deterrence justification was foreshadowed in the early and classic statement of the judicial integrity rationale by Justice Brandeis in his dissent on Olmstead v. United States, 277 U.S. 438 (1928). On one hand, Brandeis noted that judicial exclusion of evidence obtained through the illegal acts of government agents is necessary as an end in itself-to avoid judicial "contamination." Id. at 484 (Brandeis, J., dissenting). On the other hand, he recognized that it is a means "to maintain respect for law ... [and] to promote confidence in the administration of justice." Id. For an interesting discussion of the collapse of judicial integrity as an independently functioning justification for the exclusionary rule, see Schrock \& Welsh, Up From Calandra: The Exclusionary Rule as a Constitutional Requirement, 59 Minn. L. Rev. 251, 263-88 (1974).

30. 232 U.S. 383 (1914). 
deterrence. ${ }^{31}$ Deterrence was first acknowledged some thirty-five years later in Wolf v. Colorado, ${ }^{32}$ in which the Court declined to apply the Weeks rule to the states. Exclusion was considered as but one among several means available to the states to effectuate the substantive protection from unreasonable searches and seizures guaranteed by the fourth and fourteenth amendments. ${ }^{33}$ Wolf was overruled in Mapp v. Ohio,$^{34}$ in which the Court held that the states were required by the fourteenth amendment's due process clause to exclude illegally seized evidence. Deterrence was one of several justifications presented for exclusion. ${ }^{35}$ Exclusion was also described as an "essential part of the right to privacy" ${ }^{36}$ guaranteed by fourteenth amendment due process; as necessary to prevent the use of evidence that is "tantamount to coerced testimony" $;{ }^{37}$ and as a measure to preserve judicial integrity. ${ }^{38}$ Deterrence plainly was not the sole or primary basis for exclusion. The Court in Mapp noted that the failure of the states since Wolf to develop alternative methods for deterring unreasonable searches and seizures was "not basically relevant" to its decision..$^{39}$

The Stone Court considered the personal constitutional right of the defendant to be the sole alternative to deterrence as a justification for exclusion. ${ }^{40}$ It concluded, however, that the personal right rationale was no longer tenable in light of post-Mapp decisions, such as Linkletter $v$. Walker, ${ }^{41}$ and United States $v$. Calandra. ${ }^{42}$ Linkletter had refused to give full retroactive effect to Mapp, and Calandra had declined to apply the exclusionary rule in grand jury proceedings. The Stone Court stated that the rationale for these holdings had been that the deterrent purpose of the exclusionary rule would not be served by its application in these circumstances. ${ }^{43}$ The Court in Stone also relied on Walder $v$. United States, ${ }^{44}$ a pre-Mapp decision which held that

31. Justice Day explained that exclusion was necessary because " $[t]$ sanction such proceedings would be to affirm by judicial decision a manifest neglect if not an open defiance of the prohibitions of the Constitution, intended for the protection of the people against such unauthorized action." Id. at 394.

32. 338 U.S. 25 (1949).

33. This view was expressed by Justice Frankfurter, who wrote the majority opinion: Granting that in practice the exclusion of evidence may be an effective way of deterring unreasonable searches, it is not for this Court to condemn as falling below the minimal standard assured by the Due Process Clause a State's reliance upon other methods which, if consistently enforced, would be equally effective.

Id. at 31.

34. 367 U.S. 643 (1961).

35. For instance, Justice Clark stated in the Court's opinion that "the purpose of the exclusionary rule is to deter-to compel respect for the constitutional guaranty in the only effectively available way-by removing the incentive to disregard it." Id. at 656 (quoting from Elkins v. United States, 364 U.S. 206, 217 (1960)).

36. 367 U.S. at 656 .

37. Id.

38. Id. at 659 .

39. Id. at 651 .

40. 428 U.S. at $486-88$.

41. 381 U.S. 618 (1965).

42. 414 U.S. 338 (1974).

43. 428 U.S. at $486-87$.

44. 347 U.S. 62 (1954). 
Weeks did not prohibit the use of unlawfully seized evidence to impeach a defendant's testimony in a federal prosecution.

These cases, however, do not establish the proposition the Court finds in them: that a conviction based on illegally seized evidence violates no personal constitutional right of the defendant. Calandra and Walder rejected special applications of the exclusionary rule, without impairing the principle that a conviction based on illegally seized evidence is constitutionally invalid. A refusal to extend a principle, as in Calandra and Walder, does not constitute a rejection of it.

Linkletter itself proceeds on a strong assumption of the availability of federal habeas corpus for state prisoners to raise exclusionary rule claims. First, it holds that prisoners whose convictions were not final on the date Mapp was announced are entitled to retroactive application of the rule. ${ }^{45}$ For those defendants whose convictions became final after Mapp but before the decision in Linkletter four years later, the Linkletter retroactivity ruling would be primarily theoretical absent the availability of federal habeas corpus relief, since there would be virtually no postconviction proceeding for implementing it. ${ }^{46}$ Plainly, the Court did not intend its mandate of relief to be theoretical. Second, Linkletter held that the Mapp rule did not apply to persons whose convictions had become final before the Mapp decision. This controversial ruling would have been an insignificant trifle unless there was a mechanism available for postconviction relief ${ }^{47}$ Federal habeas corpus is the classic mechanism for such relief, as the Linkletter Court was aware. In sum, Linkletter is primarily a ruling about which state defendants may obtain relief under the exclusionary rule on federal habeas corpus. ${ }^{48}$

The Stone Court further contended that its balancing approach found "expression" ${ }^{99}$ in the rule and reasoning of Alderman v. United States. ${ }^{50}$ Alderman held that defendants other than victims of an illegal search or seizure may not invoke the exclusionary rule because any deterrent benefit is outweighed by the resulting impairment to the truth-seeking process. ${ }^{51}$ Alder-

45. 381 U.S. at $638-40$.

46. In 1965, when Linkletter was decided, state post-conviction procedures for the adjudication of federal constitutional claims were the exception rather than the rule. See Case v. Nebraska, 381 U.S. 336, 338-40 (1965) (Clark, J., concurring); id. at 345-46 (Brennan, J., concurring). Moreover, assuming that Mapp claims were not reviewable under the federal habeas corpus statutes, courts in those states with post-conviction procedures coextensive with federal habeas corpus could also justifiably deny relief for Mapp claims.

47. Since four years had passed between Mapp and Linkletter, the number of pre-Mapp convictions still directly reviewable in the Supreme Court was probably small. Accordingly, the retroactivity problem would have been insubstantial unless the Linkletter Court assumed the availability of federal habeas corpus to consider Mapp claims. See Bender, The Retroactive Effect of an Overruling Constitutional Decision: Mapp v. Ohio, 110 U. Pa. L. Rev. 650, 655-60 (1962).

48. See Mishkin, The Supreme Court, 1964 Term-Foreword: The High Court, The Great Writ, and the Due Process of Time and Law, 79 Harv. L. Rev. 56, 78 n.73 (1965) ("II]f the Court in Linkletter contemplated that federal habeas corpus would never lie to enforce claims of the Mapp type, a holding in those terms would have been a relatively simple way to dispose of the problem before it.").

49. 428 U.S. at 488.

50. 394 U.S. 165 (1969).

51. 428 U.S. at $488-89$. 
man's balancing, however, does not support the balancing done in Stone. Indeed, Alderman's language suggests that a person's status as a victim of a fourth amendment violation is a sufficient basis for exclusion without regard to deterrent effect; balancing was held appropriate in Alderman solely because the defendant had not been the object of unconstitutional police action. ${ }^{52}$

Stone's legal predicate, that deterrence alone justifies exclusion, is not necessarily untenable despite (a) the Court's previous recognition that habeas corpus was available to raise Mapp exclusionary rule claims, and (b) the fact that post-Mapp decisions do not repudiate a link between exclusion and a defendant's constitutional right. In order to criticize Stone persuasively on this point, an affirmative case for the linkage must be established. Arguments that the exclusionary rule rests on a personal constitutional right fall into two legal categories: (1) those which analogize ${ }^{53}$ or couple ${ }^{54}$ the fourth and fifth

52. The Alderman Court stated:

We adhere .... to the general rule that Fourth Amendment rights are personal rights which, like some other constitutional rights may not be vicariously asserted . . . .

[W]e think there is a substantial difference for constitutional purposes between preventing the incrimination of a defendant through the very evidence illegally seized from him and suppressing evidence on the motion of a party who cannot claim this predicate for exclusion.

The necessity for that predicate was not eliminated by recognizing and acknowledging the deterrent aim of the rule .... The deterrent values of preventing the incrimination of those whose rights the police have violated have been considered sufficient to justify the suppression of probative evidence even though the case against the defendant is weakened or destroyed. We adhere to that judgment. But we are not convinced that the additional benefits of extending the exclusionary rule to other defendants would justify further encroachment upon the public interest in prosecuting those accused of crime and having them acquitted or convicted on the basis of all the evidence which exposes the truth.

394 U.S. at 174-75. Concededly, this passage is ambiguous in its explanation of the different treatment accorded victims and nonvictims. On the one hand, Alderman suggests that exclusion is a personal constitutional right. That is, fourth amendment rights are "personal" and "may not be vicariously asserted." Id. at 174. Moreover, there is a "substantial difference for constitutional purposes" between victims and nonvictims of unconstitutional searches or seizures with regard to the exclusion of evidence. Id. On the other hand, Alderman also generally justifies exclusion on the instrumental grounds of "deterrent values." Id. The Court's decision, a year earlier, in Simmons v. United States, 390 U.S. 377 (1968), tends to support the former interpretation. Holding that a defendant's testimony at a suppression hearing may not be used in the prosecution's direct case at trial, Simmons deemed it "intolerable that one constitutional right should have to be surrendered in order to assert another." Id. at 394.

53. Justice Clark analogized the exclusion of illegally seized evidence with the fifth amendment's prohibition against the evidentiary use of coerced testimony in the following obscure passage in Mapp:

[A]s to the Federal Government, the Fourth and Fifth Amendments and, as to the States, the freedom from unconscionable invasions of privacy and the freedom from convictions based upon coerced confessions do enjoy an "intimate relation" in their perpetuation of "principles of humanity and civil liberty [secured] . . . only after years of struggle," Bram v. United States, 168 U.S. 532, 543-44 (1897). They express "supplementing phases of the same constitutional purpose-to maintain inviolate large areas of personal privacy." Feldman v. United States, 322 U.S. 487, 489-90 (1944). The philosophy of each Amendment and of each freedom is complementary to, although not dependent upon, that of the other in its sphere of influence-the very least that together they assure in either sphere is that no man is to be convicted on unconstitutional evidence. Cf Rochin v. California, 342 U.S. 165, 173 (1952).

367 U.S. 643,657 (1961). See also notes $34-39$ and accompanying text supra. 
amendments; and (2) those which rely solely on the fourth amendment. 55 None of these attempts to affirmatively establish a personal constitutional right to exclusion is ultimately successful.

Efforts to justify the exclusionary rule by either analogizing or joining together the fourth and fifth amendments are traceable to Justice Bradley's opinion in Boyd v. United States ${ }^{56}$ in 1886 . He perceived an "intimate relation" 57 between these amendments, which was based on several observations. First, searches for private papers are always "unreasonable" 58 under the fourth amendment, no matter how compelling the showing of probable cause for issuance of a warrant. ${ }^{59}$ Second, such searches are also condemned by the fifth amendment. ${ }^{60}$ Finally, the fourth and fifth amendments have a common purpose of protecting personal privacy. ${ }^{61}$

Whatever the historical validity of these observations, ${ }^{62}$ and whether or not Boyd's union of the fourth and fifth amendments provided a basis for the

54. Id. at 661-66 (Black, J., concurring). Justice Black perceived the interlocking of the fourth and fifth amendments as the only tenable ground on which to bar the admission of unconstitutionally seized evidence. "[W]hen the Fourth Amendment's ban against unreasonable searches and seizures is considered together with the Fifth Amendment's ban against self-incrimination, a constitutional basis emerges which not only justifies but actually requires the exclusionary rule." Id. at 662 (Black, J., concurring).

55. Justice Clark in Mapp states that the exclusionary rule is an "essential part" of the fourth amendment, id. at 656 , and seems to derive the rule without any aid from the fifth.

56. 116 U.S. 616 (1886).

57. Id. at 633 .

58. Id.

59. Justice Bradley distinguished searches for stolen goods, contraband, or forfeited material, which the government has some right to possess, from searches for items where the individual's property interest is superior to that of the government. The former searches are allowed so long as the procedural safeguards of the fourth amendment are satisfied; the latter searches are always forbidden.

The searches for and seizure of stolen or forfeited goods, or goods liable to duties and concealed to avoid the payment thereof, are totally different things from a search for and seizure of a man's private books and papers .... The two things differ toto coelo. In one case, the government is entitled to the possession of the property; in the other it is not.

Id. at 623 .

60. See, e.g., the following remarks by Justice Bradley: "And we have been unable to perceive that the seizure of a man's private books and papers to be used in evidence against him is substantially different from compelling him to be a witness against himself." Id. at 633 .

61. Following a lengthy review of the historical underpinnings of the fourth and fifth amendments, Justice Bradley concluded that their principles

apply to all invasions on the part of the government and its employés of the sanctity of a man's home and the privacies of life. It is not the breaking of his doors, and the cummaging of his drawers, that constitutes the essence of the offence; but it is the invasion of his indefeasible right of personal security, personal liberty and private property .... In this regard the Fourth and Fifth Amendments run almost into each other.

Id. at 630 .

62. Compare Note, Search and Seizure in the Supreme Court: Shadows on the Fourth Amendment, 28 U. Chi. L. Rev. 664, 692-98 (1961), with Note, Formalism, Legal Realism, and Constitutionally Protected Privacy Under the Fourth and Fifth Amendments, 90 Harv. L. Rev. 945, 951-64 (1977) [hereinafter cited as Formalism]. 
exclusionary rule, ${ }^{63}$ subsequent Supreme Court decisions have dissolved the marriage. ${ }^{64}$ For example, Warden $v$. Hayden, ${ }^{65}$ which overruled the mere evidence doctrine, rejected the notion that paper searches are unreasonable per se. Andresen $v$. Maryland ${ }^{68}$ held that the fifth amendment does not protect against a search and seizure of private papers containing incriminating statements made by the accused, and Fisher $y$. United States ${ }^{67}$ repudiated the idea of a fifth amendment privacy interest. Consequently, a personal constitutional right to the exclusionary rule cannot presently be based on a unitary reading of the fourth and fifth amendments.

The genesis in Supreme Court jurisprudence of a personal constitutional right to the exclusionary rule premised solely on the fourth amendment is

63. Boyd held unconstitutional the compulsory production of a person's private papers as required by a federal statute for use in civil forfeiture proceedings. 116 U.S. 616 (1886). The Court's opinion emphasized the close interrelationship between the fourth and fifth amendments, and many commentators have interpreted Boyd as resting on a conjunction of the amendments. See Formalism, supra note 61, at 955 n.61. Boyd's holding, however, may equally suggest that the procedure at issue violated each of the amendments separately. Justice Bradley's fourth amendment analysis proceeded in two steps. First, despite the absence of physical intrusion by government agents, a "search and seizure," within the meaning of the fourth amendment, occurred because compelled production "effects the sole object and purpose of search and seizure." 116 U.S. at 622 . Second, he concluded that the search was "unreasonable" because paper searches are forbidden. See notes $58 \& 59$ and accompanying text supra. The fifth amendment analysis rested on the proposition that compulsion to produce incriminating documents requires witnessing against oneself. See 116 U.S. at $629-32$; note 60 supra.

Boyd did not establish the principle that evidence obtained in violation of the fourth amendment is inadmissible at trial. According to Boyd's fourth amendment analysis, the illegal search occurred contemporaneously with the production of the documents in court and their introduction into evidence. Consequently, Boyd imposed a prohibition on the search itself, rather than upon subsequent evidentiary use of the ill-gotten fruits. Nor did the Court adopt the exclusionary rule by virtue of Boyd's fifth amendment analysis that compelled production is equivalent to a search. The Court subsequently held in Adams v. New York, 192 U.S. 585 (1904), that a seizure of papers is not tantamount to their compelled production. When the federal exclusionary rule was adopted in Weeks v. United States, 232 U.S. 383 (1914), reliance was placed neither upon Boyd nor upon the mutuality between the fourth and fifth amendments.

The Court first tied the Weeks exclusionary rule to Boyd and the fifth amendment in Gouled v. United States, 255 U.S. 298 (1921), which prohibited the admission of private papers illegally seized from the defendant's office. "[T]he result is the same to one accused of crime, whether he be obliged to supply evidence against himself or whether such evidence be obtained by an illegal search of his premises and seizure of his private papers." Id. at 306. It was immediately clear that the application of Boyd and the self-incrimination rationale were not dependent on the testimonial quality of the evidence. On the same day, the Court decided Amos v. United States, 255 U.S. 313 (1921), and used identical logic to overturn a conviction based on the admission into evidence of unconstitutionally seized whiskey. Four years later, the Court described the fifth amendment basis for the Weeks exclusionary rule as "well settled." Agnello v. United States, 269 U.S. 20, 33 (1925).

64. For an interesting historical analysis suggesting that the marriage of the fourth and fifth amendments was shaky almost immediately following its inception and gradually disintegrated, see Formalism, supra note 62.

65. 387 U.S. 294 (1967).

66. 427 U.S. 463 (1976).

67. 425 U.S. 391 (1976). 
uncertain. $^{68}$ The Mapp opinion did not indicate why the exclusionary rule is an "essential part" 69 of the fourth amendment, except for saying that

without [the exclusionary] rule the freedom from state invasions of privacy would be so ephemeral and so neatly severed from its conceptual nexus with the freedom from all brutish means of coercing evidence as not to merit this Court's high regard as a freedom "implicit in 'the concept of ordered liberty." "70

This was an apparent reference to the Court's prior decision in Rochin $v$. California ${ }^{71}$ which excluded evidence gathered by forcible stomach-pumping. Rochin held that the due process clause of the fourteenth amendment forbade "convictions ... brought about by methods that offend 'a sense of justice." "72 It can be argued that this passage implies that evidence must be excluded whenever the fourth amendment is violated, since such conduct offends our sense of justice. This argument, however, begs the question whether a defendant possesses a personal constitutional right to exclusion by assuming that preservation of the defendant's personal constitutional right was the reason for exclusion in Rochin. To the contrary, the decision is more reasonably read to reflect judicial condemnation of gross official misconduct. $^{73}$

Two obstacles, both rooted in the language of the fourth amendment, must be surmounted if an exclusion right is to be anchored in the fourth amendment. In sharp contrast to the specific evidentiary limitation imposed by the fifth amendment, the fourth is silent regarding an evidentiary privilege. Moreover, the fourth amendment speaks of protecting the "people" from unreasonable searches and seizures, rather than protecting the trial rights of

68. See Monaghan, The Supreme Court, 1974 Term-Foreword: Constitutional Common Law, 89 Harv. L. Rev. 1, 3 (1975). The rationale of Justice Frankfurter in Frank v. Maryland, 359 U.S. 360 (1959), since repudiated, possibly contains the foundation of a personal constitutional rights theory of exclusion based on the fourth amendment alone. Frank held that the fourteenth amendment does not require a municipal housing inspector to possess a search warrant in order to search private premises for health hazards. Id. at 373. According to Justice Frankfurter, the fourth amendment protects two separate interests: (1) the right of the individual to be secure from unauthorized official invasions of personal privacy; and (2) the right of the individual to resist invasions designed to secure evidence which will be used against him in a criminal proceeding. Id. at 365 . This second interest, described as a right of "self-protection," id., was deemed the more fundamental, and the warrant requirement was limited to searches threatening that interest.

Although advanced to limit the warrant requirement, the self-protection theory also lends support to the proposition that a victim of an unreasonable search for evidences of crime possesses a personal constitutional right to exclusion. That is, the admission of illegally seized evidence implicates his fourth amendment interest of self-protection. The self-protection theory, however, was rejected. Frank was overruled in Camara v. Municipal Ct., 387 U.S. 523 (1967), where the Court accorded criminal suspects greater fourth amendment protection than law-abiding citizens. Id. at 539-40.

69. See note 36 and accompanying text supra.

70. 367 U.S. at 655.

71. 342 U.S. 165 (1952).

72. Id. at 173 .

73. Admission of the evidence would be "to sanction the brutal conduct ... [and] would be to afford brutality the cloak of law." 342 U.S. at 173. 
an accused. Despite persistent efforts, ${ }^{74}$ these obstacles have not been overcome, and the affirmative case for a personal constitutional right to exclusion remains unmade. Thus, Stone, presumably correctly, advances the premise that the sole justification for the exclusionary rule is deterrence. Accordingly, it is appropriate to examine the Court's cost-benefit analysis as a basis for understanding the reasoning and logic of Stone.

\section{The Cost-Benefit Analysis}

Stone's cost-benefit analysis separates the advantages and disadvantages of the exclusionary rule into two categories: those incident to the rule's application at trial and on appeal, and those incident to its application on federal collateral review. ${ }^{75}$ The benefit anticipated from the exclusionary rule's application at any stage of the criminal process is general deterrence of police misconduct. ${ }^{76}$ Exclusion removes one incentive police may have to ignore the commands of the fourth amendment, and also underscores society's high regard for the fourth amendment guarantee. ${ }^{77}$ While conceding that some deterrent benefit may accompany application of the exclusionary rule at trial and on appeal, the Stone Court maintains that its application in federal collateral proceedings is less likely to produce an incremental increase in deterrence. ${ }^{78}$ Stone found it unreasonable to assume "that law enforcement authorities would fear that federal habeas review might reveal flaws in a search or seizure that went undetected at trial and on appeal."70

Federal habeas review is traditionally perceived as a necessary surrogate for direct review in the Supreme Court, because direct review is felt inadequate to protect the constitutional rights of state criminal defendants. ${ }^{80}$ From this standpoint, the advisability of federal collateral review in Stone depends less upon deterrence of police misconduct than upon the need for federal trial court oversight to ensure that state judges respond appropriately to fourth amendment claims raised by criminal defendants. ${ }^{81}$ Stone, however, emphat-

74. See, e.g., Schrock \& Welsh, supra note 29.

75. Stone v. Powell, 428 U.S. 465, 489-95 (1976).

76. Id. at 492.

77. Id. The exclusion of unlawfully obtained evidence entails two aspects of general deterrence-direct and indirect deterrence. Direct deterrence depends on the threat of exclusion to ensure police compliance with search and seizure rules. Indirect deterrence, which operates independently of the fear of sanctions, is more long range, and depends on the socializing influence of the exclusionary rule and its imposition on law enforcement officers. See Oaks, Studying the Exclusionary Rule in Search and Seizure, 37 U. Chi. L. Rev. 665, 709-12 (1970).

78. 428 U.S. at 493.

79. Id.

80. The great numbers of petitions for certiorari filed in the Supreme Court by state prisoners, many of whom fail to file the papers necessary to inform the Court of the state proceedings, render Supreme Court review inadequate to vindicate federal constitutional rights of persons convicted in state court. See Brown v. Allen, 344 U.S. 443, $493-94$ (1953) (Frankfurter, J., concurring); Reitz, Federal Habeas Corpus: Post-conviction Remedy for State Prisoners, 108 U. Pa. L. Rev. 461, 464 (1960).

81. Advocates of expansive federal habeas corpus jurisdiction advance institutional arguments to explain why federal judges are more likely to be responsive to federal constitutional claims of a state defendant than state judges. See Wright \& Sofaer, Federal Habeas Corpus For 
ically rejects this oversight justification, proclaiming that state judges are as able as federal judges to decide fourth amendment claims and no less sympathetic to them. ${ }^{82}$ No empirical support is presented for this proposition. Indeed, the companion case to Stone, Wolff $v$. Rice, ${ }^{83}$ tends to demonstrate the opposite, for there the state court's rejection of the fourth amendment claim was contrary to established fourth amendment principles. ${ }^{84}$

On the debit side of the ledger, the Stone court notes that the exclusionary rule, whenever applied, diverts' attention from the issue of guilt or innocence, deprives the factfinder of reliable and typically probative information, and offers a windfall to the guilty. ${ }^{85}$ Moreover, significant costs generally accompany its ultilization in federal collateral proceedings: the consumption of scarce federal judicial resources, delayed finality of criminal proceedings, and friction between federal and state judiciaries. ${ }^{86}$ No countervailing benefits are found in Stone to offset these incremental costs.

The chief problem with the Court's balancing analysis is that it rests largely on untested and unproven factual assumptions. There are no data on the pivotal issue: is federal collateral review necessary to ensure adequate state court enforcement of the exclusionary rule? Additionally, the evidence upon which the Court finds collateral application of the exclusionary rule to entail substantial incremental cost is weak. For example, the contention that an unacceptable burden on the federal judiciary accompanies habeas corpus review of search and seizure claims is supported by Justice Powell's concurring opinion in Schneckloth $v$. Bustamonte, ${ }^{87}$ in which he observed the increasing number of habeas corpus petitions filed annually by state prisoners. $^{88}$ This statistic, however, does not reveal the number of fourth amendment claims raised in collateral proceedings, or the amount of federal judicial time devoted to resolving them. Similarly, the Stone Court repeats the homily that federal collateral review of state prisoners' claims tends to under-

State Prisoners: The Allocation of Fact-Finding Responsibility, 75 Yale L.J. 895, 898 n.14 (1966) (quoting Bator, Finality in Criminal Law and Federal Habeas Corpus for State Prisoners, 76 Harv. L. Rev. 441, 510 (1963)).

82. 428 U.S. at 493 n. 35 .

Despite differences in institutional environment and the unsympathetic attitude to federal constitutional claims of some state judges in years past, we are unwilling to assume that there now exists a general lack of appropriate sensitivity to constitutional rights in the trial and appellate courts of the several States.

Id. at 494 n.35.

83. 428 U.S. 465 (1976).

84. The issue in Wolff was whether the pdlice presented sufficient facts to establish probable cause for the issuance of a search warrant. The state court determined that the warrant was supported by probable cause, and considered evidence which was adduced at the suppression hearing but not presented to the magistrate who issued the warrant. State v. Rice, $188 \mathrm{Neb} .728$, 199 N.W.2d 480 (1972). This was in clear contravention of the standard announced in Spinelli v. United States, 393 U.S. 410, 413 n.3 (1969), and Aguilar v. Texas, 378 U.S. 108, 109 n.1 (1964). See Rice v. Wolff, 513 F.2d 1280, 1285-86 (8th Cir. 1975), rev'd sub nom. Stone v. Powell, 428 U.S. 465 (1976).

85. 428 U.S. at 490.

86. 428 U.S. at $491 \mathrm{n} .31$.

87. 412 U.S. 218, 259 (1973) (Powell, J., concurring). See 428 U.S. at 491 n.31.

88. 412 U.S. 260 n. 14 . 
mine the federal system by generating friction between the state and federal judiciaries, ${ }^{89}$ and calls to mind the specter of a single district judge overruling the highest appellate state court on a question of federal constitutional law..$^{00}$ Again, the Court offers no factual support for the proposition that this theoretical possibility actually occurs. Rather, it is likely that many habeas corpus petitioners present fourth amendment claims that have neither been accepted for consideration by the state's highest court nor been given written consideration by any other state tribunal.

The Stone Court can be justly criticized for presenting an insufficient factual base to support its assessment of the costs and benefits of fourth amendment habeas litigation in federal court. On the other hand, similar criticism can be addressed to the proponents of such review. No convincing empirical data are available to support either side of the argument, and the prospect for any to be forthcoming is dim.91 Nevertheless, if reliable data were available, and if agreement could be reached as to the identity and measurement of the relevant costs and benefits, the controversy over the desirability of federal collateral review of fourth amendment claims would not end. Rather, the argument would shift to the weight that should attach to each of the various conflicting interests. ${ }^{92}$

\section{The Exception}

The Stone Court did not completely bar federal habeas litigation of fourth amendment claims, but rather, created an exception where "an opportunity for full and fair litigation" has been denied. ${ }^{93}$ No explanation for the exception was given, nor was any direct guidance for its interpretation provided except for a cryptic reference to Townsend $v$. Sain. ${ }^{94}$

The reference to Townsend has provoked considerable lower court discussion. The dominant view is that Townsend provides only limited assistance

89. 428 U.S. at 491 ก.31.

90. See the concurring opinion of Justice Powell in Schneckloth v. Bustamonte, 412 U.S. 218, 263-65 (1973) (Powell, J., concurring), where he recalls the remarks of Justice Paul C. Reardon of the Massachusetts Supreme Judicial Court regarding the denigration of state courts and " "humiliation of review from the full bench of the highest State appellate court to a single United States District Court Judge' " occasioned by federal habeas corpus review.

91. See Shapiro, Federal Habeas Corpus: A Study in Massachusetts, 87 Harv. L. Rev. 321, 324-25 (1973).

92. For example, what incremental increase in federal-state friction would be warranted to attain an additional unit of deterrence? The Stone majority opinion does not address these types of issues. In this respect, Stone's balancing analysis resembles an "engineer's black box-the Court throws the interests in at one end, and a result emerges from the other." Tushnet, Judicial Revision of the Habeas Corpus Statutes: A Note on Schneckloth v. Bustamonte, 1975 Wis. L. Rev. 484, 501 (1975).

93. See note 2 and accompanying text supra.

94. The Court makes a "cf." reference to Townsend v. Sain, 372 U.S. 293 (1963), after one of the several places in the majority opinion where reference is made to the opportunity for full and fair litigation. 428 U.S. at 494 n.36. According to A Uniform System of Citation 7 (12th ed. 1976), the "cf." signal indicates that the cited authority "supports a proposition different from" but "sufficiently analogous" to lend some support to the text. The Stone opinion, however, does not elaborate on their similarity. 
in defining the content of the Stone exception..$^{95}$ This view is probably an exaggeration of Townsend's usefulness. Townsend set forth standards governing the granting of an evidentiary hearing by a federal court in a habeas corpus proceeding. These standards include:

(1) the merits of the factual dispute were not resolved in the state hearing; (2) the state factual determination is not fairly supported by the record as a whole; (3) the fact-finding procedure employed by the state court was not adequate to afford a full and fair hearing; (4) there is a substantial allegation of newly discovered evidence; (5) the material facts were not adequately developed at the state court hearing; or (6) for any reason it appears that the state trier of fact did not afford the habeas applicant a full and fair fact hearing. ${ }^{96}$

These criteria are of little help in defining the content of the Court's phrase "an opportunity for full and fair litigation" for the purpose of determining the availability vel non of federal habeas review of fourth amendment claims. The Townsend standards assume that a state evidentiary hearing was held. ${ }^{97}$ Consequently, they are irrelevant to the issue of whether the petitioner received a sufficient opportunity to obtain a hearing when none was held. ${ }^{98}$ In addition, even if a state evidentiary hearing was held, the criteria focus on the resolution of factual disputes, and are not pertinent when either the issues raised on habeas corpus are solely legal questions, ${ }^{99}$ involve mixed questions of law and fact, ${ }^{100}$ or relate to the adequacy of the state appellate process. ${ }^{101}$

More fundamentally, the premises of Townsend and Stone are at odds. ${ }^{102}$ Townsend focuses on the potential for error in state court factfinding to justify a de novo hearing in federal court, ${ }^{103}$ while Stone underscores the ability and integrity of state judges to justify curtailment of federal habeas review. ${ }^{104}$ Further, although the inquiries pursued under Townsend and Stone are similarly formulated, i.e., whether a habeas petitioner was afforded a full and fair hearing, the consequences of these determinations are

95. See, e.g., Doleman v. Muncy, 579 F.2d 1258, 1263-65 (4th Cir. 1978); Gates v. Henderson, 568 F.2d 830, 837-38 (2d Cir. 1977), cert. denied, 434 U.S. 1038 (1978); O'Berry v. Wainwright, 546 F.2d 1204, 1210-13 (5th Cir.), cert. denied, 433 U.S. 911 (1977). But see Gibson v. Jackson, 578 F.2d 1045, 1053 (5th Cir. 1978) (Rubin, J., addendum), cert. denied, 439 U.S. 1119 (1979); Curry v. Garrison, 423 F. Supp. 109, 110 (W.D.N.C. 1976), appeal dismissed, 565 F.2d 156 (4th Cir. 1977).

96. 372 U.S. at 313.

97. 372 U.S. at 312-13.

98. See, e.g., Gates v. Henderson, 568 F.2d 830, 837 (2d Cir. 1977) (rehearing en banc), cert. denied, 434 U.S. 1038 (1978).

99. See, e.g., O'Berry v. Wainwright, 546 F.2d 1204, 1211 (5th Cir.), cert. denied, 433 U.S. 911 (1977).

100. See, e.g., Graves v. Estelle, 556 F.2d 743, 746 (5th Cir. 1977).

101. See, e.g., Mack v. Cupp, 564 F.2d 898, 901 (9th Cir. 1977). (1980).

102. See, e.g., Palmigiano v. Houle, 618 F.2d 877, 882 (1st Cir.), cert. denied, 101 S. Ct. 272

103. 372 U.S. at 314-16.

104. See note 82 and accompanying text supra. 
radically different. Under Townsend, if the district court determines that the state hearing was full and fair, the only effect is that it must accept the state court findings of fact in its independent review of legal rulings. ${ }^{105}$ On the other hand, a determination under Stone that state court consideration of the fourth amendment claim was full and fair effectively results in denial of all review, ${ }^{106}$ and is tantamount to a lack of jurisdiction over the matter. ${ }^{107}$ Since Stone, in essence, establishes a jurisdictional limit on habeas corpus review, presumably something more is necessary to overcome this barrier than is required to justify a federal evidentiary hearing where the power to undertake federal review is beyond doubt. In light of these significant differences, the reference to Townsend provides little guidance for elucidating the content of the exception.

It has been suggested that the exception is an outgrowth of the view expressed by Professor Bator, ${ }^{108}$ that the proper role of federal habeas corpus review of state prisoners' constitutional claims is "not to assure that federal questions are correctly decided, but to assure that they are decided by procedures calculated to reach a correct decision." 109 To be sure, Professor Bator's ideas have exercised considerable influence on the shaping of Justice Powell's individual views concerning federal habeas corpus. ${ }^{110}$ They are inadequate, however, to rationalize Stone's limitation on fourth amendment litigation or its exception. Bator's thesis is based largely on the history of habeas corpus practice in America prior to the decision of Brown v. Allen ${ }^{111}$ in 1953, which applied habeas review to constitutional claims generally, and upon policy considerations which emphasize the importance of finality in criminal cases. ${ }^{112}$ Bator posits that under the federal habeas corpus statute, review of state prisoners' constitutional claims is justified in only two instances-where either the state committing court lacked jurisdiction in the narrow sense of judicial competence, or the state judicial system did not afford a fair and rational process for meaningful consideration of their claims. ${ }^{113}$ Stone, on the other hand, rests on a constitutional judgment about the source of the exclusionary rule, i.e., that exclusion is not a personal constitutional right, and on a utilitarian judgment concerning the rule's application in various fora. Stone does not posit an interpretation of the habeas

105. 372 U.S. at $312-13,318$.

106. 428 U.S. at 494-95.

107. As Chief Judge Brown concluded in O'Berry, "[d]espite the assertions of the Supreme Court in Stone to the contrary, we would be blind to reality to pretend that the practical effect of that decision is not a limitation on federal court jurisdiction." O'Berry v. Wainwright, 546 F.2d 1204, 1211-12 (5th Cir.), cert. denied, 433 U.S. 911 (1977).

108. Bator, Finality In Criminal Law And Federal Habeas Corpus For State Prisoners, 76 Harv. L. Rev. 441 (1963).

109. Seidman, supra note 4 , at 458 .

110. In his concurring opinion in Schneckloth v. Bustamonte, 412 U.S. 218, 250 (1973), Justice Powell repeatedly relied on Professor Bator's article. See, e.g., id. at $253 \mathrm{nn} .3$ \& 5, 255 n.7, 259 n.13.

111. 344 U.S. 443 (1953).

112. Bator, supra note 108 , at $444-53,463-99$.

113. See generally Bator, supra note 108 , at 523-28. 
corpus statute. Moreover, the limitation urged by Bator would apply to constitutional claims generally, and not solely to fourth amendment exclusionary rule claims. To date, however, a majority of the Court has declined to extend Stone's reach beyond fourth amendment claims. ${ }^{114}$ Thus, the exception cannot be derived merely from an interpretation of the habeas corpus statute. ${ }^{115}$

\section{The "OpPortuntty For FUll and Fair Litigation" STANDARD IN THE LOWER FederaI COURTS}

\section{A. The Courts' Interpretations of the Standard}

The term "opportunity," as used in the requirement of an "opportunity for full and fair litigation," contemplates both the opportunity to raise a fourth amendment claim in the state courts and the opportunity to have the claim adjudicated. ${ }^{116}$ A fourth amendment claim presented by a state prisoner to a federal habeas court may or may not have been decided on the merits by the state courts. If it was considered and rejected on the merits, the federal issue is whether the opportunity for adjudication was full and fair. Alternatively, if there was no decision on the merits, the issue is whether the opportunity for raising the claim was full and fair.

1. Application of the Standard When the Claim Was Rejected on its Merits by the State Courts. The lower federal courts generally agree that an erroneous fourth amendment decision by the state courts, without more, does not constitute denial of an "opportunity for full and fair litigation." 117 It is of no consequence whether the state courts employed an incorrect legal standard, ${ }^{118}$ misapplied the correct standard, ${ }^{110}$ or erred in finding the underlying

114. See, e.g., Rose v. Mitchell, 443 U.S. 545 (1979), which refused to extend Stone to bar habeas review of a state prisoner's grand jury discrimination claim.

115. The Stone exception may also be explained on the theory that denial of an opportunity for full and fair hearing constitutes an independent denial of due process, i.e., what Justice Brandeis referred to as "due process in the primary sense,-whether [a litigant] has had an opportunity to present its case and be heard in its support." Brinkerhoff-Faris Trust \& Savings Co. v. Hill, 281 U.S. 673, 681 (1930). It is unlikely, however, that the Stone Court intended to base the exception on due process, given its underlying premises that the admission of illegally seized evidence implicates neither a personal constitutional right of the accused nor the basic fairness of the trial.

116. Justice Powell formulated the standard more precisely in his concurring opinion in Schneckloth, where he maintained that federal collateral review of a state prisoner's fourth amendment claim should be confined solely to the question of "whether the petitioner was provided a fair opportunity to raise and have adjudicated the question in state courts." Schneckloth v. Bustamonte, 412 U.S. 218, 250 (1973) (Powell, J., concurring).

117. See, e.g., Mack v. Cupp, 564 F.2d 898, 901 (9th Cir. 1977) ("Under Stone a federal district court may not relitigate a fourth amendment issue tried fully and fairly in a state court, regardless of its view of the correctness of the state decision."). Cf. generally United States ex rel. Maxey v. Morris, 591 F.2d 386, 389 (7th Cir.), cert. denied, 442 U.S. 912 (1979); Dupont v. Hall, 555 F.2d 15, 17 (1st Cir. 1977); United States ex rel. Petillo v. New Jersey, 562 F.2d 903, 906 (3d Cir. 1977).

118. See, e.g., United States ex rel. Carbone v. Manson, 447 F. Supp. 611, 616 (D. Conn. 1978).

119. See, e.g., Swicegood v. Alabama, 577 F.2d 1322, 1324 (5th Cir. 1978); Holmberg v. Parratt, 548 F.2d 745, 746 (8th Cir.), cert. denied, 431 U.S. 969 (1977). 
facts. ${ }^{120}$ If Stone's restrictions could be avoided simply by alleging that the state courts erred in deciding a fourth amendment claim, many lower courts fear that Stone's bar would become a nullity, since petitioners would routinely allege the necessary error. ${ }^{121}$ Further, this interpretation is considered consistent with Stone's observation that state judges are as receptive and competent to decide search and seizure claims as federal judges, ${ }^{122}$ and with the Court's concern for comity and finality in state criminal proceedings. ${ }^{123}$ Finally, as previously noted, in Wolff, the companion case decided with Stone, "[T]he petitioner's Fourth Amendment right was clearly violated by an illegal search . . . but the Supreme Court did not review that claim since it held that the petitioner had a full and fair hearing in the state court."124

Not all federal courts, however, accept the view that habeas corpus review is unavailable solely because the state decision was erroneous. For instance, a Tenth Circuit panel concluded that a habeas court should address the merits of a fourth amendment claim whenever the "state court wilfully refuses to apply the correct and controlling constitutional standards." 125 Stone's requirement of "opportunity for full and fair litigation" was perceived as encompassing "colorable application of the correct Fourth Amendment constitutional standards."128 This decision, however, is without progeny. ${ }^{127}$

Most lower federal courts interpret Stone's use of the term "opportunity" to mean that habeas corpus review of a fourth amendment claim may be available only where state process was defective. ${ }^{128}$ Thus, the initial consider-

120. See, e.g., Mack v. Cupp, 564 F.2d 898, 902 (9th Cir. 1977); United States ex rel. Petillo v. New Jersey, 562 F.2d 903, 907 (3rd Cir. 1977).

121. See, e.g., Swicegood v. Alabama, 577 F.2d 1322, 1324 (5th Cir. 1978); United States ex rel. Carbone v. Manson, 447 F. Supp. 611, 616 (D. Conn. 1978). For instance, the Carbone court denied the petitions for habeas corpus and dismissed the claim that the state court employed an incorrect legal standard.

If this Court were to rule that Stone does not preclude habeas corpus review because the Connecticut Supreme Court did not apply an appropriate standard of review in deciding the Fourth Amendment claim, it would be the rare state prisoner indeed who would not allege that the state court had applied an improper standard when the state court ruled adversely to him in deciding his Fourth Amendment claim.

Id. at 616 .

122. See, e.g., Graves v. Estelle, 556 F.2d 743, 746 (5th Cir. 1977).

123. See, e.g., Hines v. Auger, 550 F.2d 1094, 1097 (8th Cir. 1977).

124. Holmberg v. Parratt, 548 F.2d 745, 746 n.1 (8th Cir.), cert. denied, 431 U.S. 969 (1977); see note 84 and accompanying text supra.

125. Gamble v. Oklahoma, 583 F.2d 1161, 1165 (10th Cir. 1978).

126. Id. Observing that the Stone opinion interchanges the phrases "full and fair litigation" and "full and fair consideration," the Gamble court reasoned that "in some instances more than procedural opportunity to raise and litigate a Fourth Amendment claim is required. Indeed, consideration connotes the actual evaluation of a claim under the correct constitutional standard." Id. at 1165 n.2.

127. Infrequently cited, Gamble has never been employed as authority for reaching the merits of a fourth amendment claim on habeas corpus. Indeed, it has been narrowly read by one court to apply only when there is flagrant disregard of Supreme Court precedent. United States ex rel. Maxey v. Morris, 591 F.2d 386, 390 (7th Cir.), cert. denied, 442 U.S. 912 (1979).

128. See, e.g., Doleman v. Muncy, 579 F.2d 1258, 1264-65 (4th Cir. 1978); Hines v. Auger, 550 F.2d 1094, 1097-98 (8th Cir. 1977); United States ex rel. Conroy v. Bombard, 426 F. Supp. 97, 110 (S.D.N.Y. 1976). 
ation of a fourth amendment claim by a habeas court is limited to whether the process of adjudication was satisfactory. Unless the petitioner alleges that some procedural defect impaired litigation of his fourth amendment claim, courts read Stone to require dismissal. ${ }^{129}$ Given the dichotomy between process and substance, the classification of an alleged error as procedural or substantive is critical to the availability of habeas review.

The significance of this procedural-substantive distinction may be seen in United States ex rel. Conroy v. Bombard, ${ }^{130}$ in which the habeas petitioner claimed that unconstitutional wiretapping was the source of prosecutorial evidence used against him at trial. The police in Conroy had obtained a court order authorizing a wiretap on petitioner's telephone and, when the order expired, continued to eavesdrop for several days before obtaining a second order. The state courts ruled that only the first wiretap order was legal, but concluded that the prosecution's evidence had been obtained independently of any wiretapping. ${ }^{131}$ Petitioner challenged the state court rulings in his petition for habeas corpus. Treating the challenge to the first wiretap order as substantive, the district court summarily rejected it: "[Petitioner] asserts that the hearing was unfair because the court interpreted the facts differently than [he] would have preferred, and issued a ruling contrary to [his] posture . . . . It is precisely this manner of claim which the district courts, under Stone $v$. Powell, are precluded from hearing ...." 132

The Conroy court, however, inquired more deeply into the independent source claim, because petitioner alleged a procedural defect in the state proceedings. Petitioner had urged that the prosecution was precluded from proving an independent source for its evidence, because state officers had destroyed some of the wiretap tapes in bad faith, which effectively prevented petitioner from pursuing the taint question. ${ }^{133}$ After examining the record, the district court rejected the claim that process was inadequate: 134 "Petitioner's allegations that the tapes were unavailable because of bad faith are really complaints about the hearing result, not the procedure. He had the opportunity to argue his point at the state hearing; after examining the facts, the hearing court disagreed." 135

129. See, e.g., Doleman v. Muncy, 579 F.2d 1258, 1265 (4th Cir. 1978).

130. 426 F. Supp. 97 (S.D.N.Y. 1976).

131. Id. at 100-01.

132. Id. at 102 .

133. Id. at $101,103$.

134. Id. at 107-08. Petitioner contended that the state hearing was procedurally defective because restrictions on defense cross-examination prevented him from demonstrating bad faith destruction of the tapes. The Conroy court, after examining the record, concluded that the curtailment of cross-examination was proper. Consequently, the court dismissed the petitioner's claim that the independent source issue should be relitigated.

Petitioner has not demonstrated that the available state procedures were inadequate or otherwise prevented him from presenting his claims, nor has he shown that the conduct of the hearing judge circumvented those procedures. Instead, he maintains that the hearing court's conclusions were incorrect, and he urges that rulings more favorable to his position be imposed on the state court by a federal court. . . . Stone . . . militates against such action by a district court.

Id. at 109.

135. Id. at 108. 
It is possible to conceive of a consequential procedural error, however. For example, a habeas court may find that the state trial judge erroneously required a defendant to carry the burden of proof on the issue of probable cause. The federal issue then is whether this procedural defect constituted a denial of an "opportunity for full and fair litigation." Habeas courts typically resolve this issue by examining the totality of the state court proceedings and determining if the state appellate process was adequate to correct trial error. ${ }^{138}$ Consequently, if a trial court erroneously requires a defendant to prove the absence of probable cause, but the error is subsequently corrected on appeal without change in the result, then habeas corpus review may be denied. ${ }^{137}$

In the end, wherever state courts reject fourth amendment claims on their merits, habeas applicants are generally unsuccessful in obtaining federal review on the basis of alleged state procedural defects at trial or on appeal. ${ }^{138}$ Allegations that state trial courts misallocated the burden of proof, ${ }^{130}$ erroneously refused to hold an evidentiary hearing, ${ }^{140}$ or failed to hear relevant evidence ${ }^{141}$ have not succeeded. One rationale used is that the facts are sufficiently well developed in the record so that errors may be corrected on appeal. Conversely, the petitioner may be held responsible for the inadequate factual development in the record on appeal, also resulting in dismissal of the petition. ${ }^{142}$ Contentions regarding the procedural defectiveness of the appellate disposition of a fourth amendment claim have also failed. ${ }^{143}$

136. See, e.g., Pulver v. Cunningham, 419 F. Supp. 1221, 1224 (S.D.N.Y. 1976), aff'd, 562 F.2d 198 (2d Cir. 1977).

137. See, e.g., Palmigiano v. Houle, 618 F.2d 877, 878, 883 (1st Cir.), cert. denied, $101 \mathrm{~S}$. Ct. 272 (1980); Pignone v. Sands, 589 F.2d 76, 78, 80 (1st Cir. 1978) (alternative holding). The state appellate court in Palmigiano had concluded that the erroneous placement of the burden of proof was not a factor in the trial court's findings; consequently, the habeas court determined that the error did not distort the review process. $618 \mathrm{~F} .2 \mathrm{~d}$ at 883 .

138. But see Doescher v. Estelle, 616 F.2d 205 (5th Cir. 1980).

139. See, e.g., Palmigiano v. Houle, 618 F.2d 877 (1st Cir.), cert. denied, 101 S. Ct. 272 (1980); Pignone v. Sands, 589 F.2d 76 (1st Cir. 1978).

140. See, e.g., Lewis v. Gourley, 560 F.2d 393 (8th Cir.), cert. denied, 434 U.S. 987 (1977); Mack v. Cupp, 564 F.2d 898 (9th Cir. 1977); Simmons v. Clemente, 552 F.2d 65 (2d Cir. 1977). Lewis held that a second evidentiary hearing was not required on a motion to suppress when petitioner's first trial ended in a mistrial, and a plenary hearing had occurred prior to his first trial. 560 F.2d at 394. Similarly, the Mack court agreed with the state trial judge's conclusion that an evidentiary hearing was unnecessary in light of the petitioner's failure to set forth sufficient facts in his supporting affidavit that specifically contradicted the prosecution's averments. 564 F.2d at 901. Finally, Simmons also held it unnecessary for a state coram nobis judge to hold an evidentiary hearing, when the same judge presided at the petitioner's pre-trial hearings and trial, and the petitioner had not alleged the subsequent discovery of new evidence. $552 \mathrm{~F} .2 \mathrm{~d}$ at 68-69.

141. See, e.g., Pignone v. Sands, 589 F.2d 76 (1st Cir. 1978), which held, as an alternative ground for decision, that the petitioner could not complain about a state trial court's refusal to consider evidence of exigent circumstances at a hearing on a motion to suppress when petitioner had elected to proceed on stipulated facts during an earlier proceeding.

142. See, e.g., Pignone v. Sands, 589 F.2d 76 (1st Cir. 1978); O'Berry v. Wainwright, 546 F.2d 1204 (5th Cir.), cert. denied, 433 U.S. 911 (1977).

143. See, e.g., Tackno v. Blackburn, 571 F.2d 1383 (5th Cir. 1978); Hines v. Auger, 550 F.2d 1094, 1098 (8th Cir. 1977). Examples of alleged procedural defects include summary rejection, or dismissal without specific mention, of fourth amendment claims by appellate courts. 
2. Application of the Standard when the Claim Was Not Decided on its Merits by the State Courts. Focusing on the use of the word "opportunity" in the exception, the lower federal courts generally conclude that actual litigation on the merits in the state courts is not necessary to invoke Stone's ban on collateral review. ${ }^{144}$ Rather, the issue is whether the defendant had the opportunity to litigate as envisioned by Stone, regardless of whether he availed himself of it. ${ }^{145}$

In cases where the fourth amendment claim was not raised in the state courts, or where the state courts refused to reach the merits because of a procedural default attributed to the defendant, several standards have been suggested to determine the availability of federal collateral review: "deliberate bypass," 146 "cause and prejudice," 147 adequate state corrective process, ${ }^{148}$ and independent and adequate state ground. ${ }^{149}$

Under the "deliberate bypass" standard enunciated by the Supreme Court in Fay $v$. Noia, ${ }^{150}$ a petition for habeas corpus review is not precluded when the defendant fails to raise, or improperly raises a constitutional claim in the state courts, unless state procedures was intentionally waived. ${ }^{151}$ Although neither Fay nor the "deliberate bypass" standard were mentioned in the Stone majority opinion, Fay appears to have been effectively overruled with respect to fourth amendment claims. ${ }^{152}$ The intentional-waiver test rests on the

144. The Fifth Circuit decision of Caver v. Alabama, 577 F.2d 1188 (5th Cir. 1978), offered this explanation.

An "opportunity for full and fair litigation" means just that: an opportunity. If a state provides the processes whereby a defendant can obtain full and fair litigation of a fourth amendment claim, Stone v. Powell bars federal habeas corpus consideration of that claim whether or not the defendant employs those processes.

Id. at 1192. Cf. generally United States ex rel. Maxey v. Morris, 591 F.2d 386, 388 (7th Cir.), cert. denied, 442 U.S. 912 (1979); Sallie v. North Carolina, 587 F.2d 636, 639 (4th Cir. 1978), cert. denied, 441 U.S. 925 (1979); Gates v. Henderson, 568 F.2d 830, 838-40 (2d Cir. 1977), cert. denied, 434 U.S. 1038 (1978).

145. See, e.g., Doleman v. Muncy, 579 F.2d 1258, 1265 (4th Cir. 1978); note 144 supra.

146. See O'Berry v. Wainwright, 546 F.2d 1204, 1222-23 (5th Cir.) (Goldberg, J., dissenting), cert. denied, 433 U.S. 911 (1977).

147. See Gates v. Henderson, 568 F.2d 830, 842-44 (2d Cir. 1977) (Oakes, J., concurring) (rehearing en banc), cert. denied, 434 U.S. 1038 (1978).

148. See cases cited in note 144 supra.

149. See Johnson v. Meacham, 570 F.2d 918 (10th Cir. 1978); O'Berry v. Wainwright, 546 F.2d 1204, 1216-17 (5th Cir.), cert. denied, 433 U.S. 911 (1977).

150. 372 U.S. 391 (1963).

151. Justice Brennan narrowly defined the circumstances in which habeas corpus review was precluded as a consequence of the petitioner's failure to raise a federal claim in state court.

If a habeas applicant, after consultation with competent counsel or otherwise, understandingly and knowingly forewent the privilege of seeking to vindicate his federal claims in the state courts, whether for strategic, tactical, or any other reasons that can fairly be described as the deliberate by-passing of state procedures, then it is open to the federal court on habeas to deny him all relief if the state courts refused to entertain his federal claim on the merits-though of course only after the federal court has satisfied itself, by holding a hearing or by some other means, of the facts bearing upon the applicant's default.

Id. at 439.

152. See Gates v. Henderson, 568 F.2d 830, 838-39 (2d Cir. 1977) (rehearing en banc), cert. denied, 434 U.S. 1038 (1978). 
principle that a convicted defendant should not lose his "last opportunity to vindicate his constitutional rights" because of a state procedural default. ${ }^{153}$ This rationale, however, will not support federal collateral review of fourth amendment exclusionary rule claims in light of Stone's teachings that exclusion is not a personal constitutional right of the accused. Moreover, deterrence presumably would not be enhanced by the "deliberate bypass" standard. That is, it is unreasonable to assume police will consider the two-fold possibility that (1) an unconstitutional search and seizure will go undetected or unremedied in the state courts because of a defendant's unintentional procedural default, and (2) such unconstitutional conduct will be subjected to federal collateral review under the intentional-waiver standard and will be uncovered.

Those who urge the adoption of the "cause and prejudice" standard contend that it ought generally to govern habeas review of alleged trial-type errors that do not impair the integrity of state factfinding, when the state courts did not decide the claim on the merits because of a procedural default. ${ }^{154}$ The cause and prejudice standard was utilized by the Supreme Court in Francis $v$. Henderson, ${ }^{155}$ which concerned a state prisoner's failure to raise a timely challenge to the racial composition of the grand jury, and the consequent denial of state court adjudication. Francis held that subsequent federal collateral review was barred, unless the petitioner could show "cause" for his failure to make a timely motion and "actual prejudice" from the alleged racial imbalance. ${ }^{156}$ The Court similarly applied the "cause and prejudice" standard in Wainwright $v$. Sykes, ${ }^{157}$ and denied collateral consideration of a Miranda claim that the state courts had declined to consider, because the petitioner failed to comply with the state's contemporaneousobjection rule. 158

The majority of courts, however, interpret Stone's exception even more restrictively and preclude federal review if the state provided "corrective process" for litigation of a fourth amendment claim..$^{159}$ Under this restrictive interpretation, habeas relief is available only if a petitioner was "precluded from utilizing [such corrective process] by reason of an unconscionable break-

153. Fay, 372 U.S. at 432.

154. See, e.g., Gates v. Henderson, 568 F.2d 830, 842-44 (2d Cir. 1977) (Oakes, J., concurring), cert. denied, 434 U.S. 1038 (1978).

155. 425 U.S. 536 (1976).

156. Id. at 425. See also Davis v. United States, 411 U.S. 233 (1973), which first enunciated the "cause and prejudice" standard. The federal prisoner in Davis brought an action for collateral relief under 28 U.S.C. $\$ 2255$ and challenged, for the first time, the makeup of the grand jury which had indicted him. Id. at 234-36.

157. 433 U.S. 72 (1977).

158. Id. at $74,86$.

159. See note 144 supra. The "corrective process" formulation stems in part from a law review article by Professor Paul M. Bator, supra note 108, in which he urged a more limited scope of federal habeas corpus jurisidiction confined to the issue of whether the state judicial system provided the petitioner with a meaningful opportunity to litigate his constitutional claims in an unbiased forum using rational procedures. Id. at 455-56. Cf. generally text accompanying notes 108-15 supra. 
down in that process." 180 A somewhat similar interpretation of the exception forecloses habeas relief when state courts refuse to reach the merits of a fourth amendment claim on the basis of an independent and adequate state procedural ground. ${ }^{161}$ The independent-and-adequate-state-ground test, like the corrective-process standard, is more restrictive than "cause and prejudice." If the state procedural rule barring consideration of the merits serves a legitimate state interest and does not discriminate against federal claims, habeas litigation is foreclosed. Neither the cause of the failure to comply with the procedural rule nor the effect of any resulting prejudice to the defendant is considered. ${ }^{162}$

Application of the corrective-process and the independent-and-adequatestate-ground standards tend to produce the same results. In theory, however, the latter standard focuses upon the reasonableness and legitimacy of the state's forfeiture rule, while the former evaluates the adequacy of the state system for raising fourth amendment claims. One significant procedural difference is that the independent-and-adequate-state-ground standard, unlike the corrective-process standard, requires a state court ruling of procedural default. Thus, a court that reads the exception narrowly might utilize the independent-and-adequate-state-ground standard where the state courts refused to consider a fourth amendment claim, and the corrective-process standard where the claim is raised for the first time on habeas corpus. ${ }^{163}$

In some situations, the absence of a fourth amendment decision on the merits may be the product of judicial oversight as opposed to a procedural default attributable to the defendant. For example, suppose a state trial court refuses to consider a fourth amendment exclusionary rule claim before trial because it is premature. Later, the same court refuses to consider it after trial because it could be raised on appeal. Subsequently, the appellate court declines to consider it, based on a belief that the trial court had previously rejected it on the merits. Presented with essentially these facts, one court permitted federal collateral litigation on the theory that the petitioner had

160. Gates v. Henderson, 568 F.2d 830, 840 (2d Cir. 1977) (rehearing en banc), cert. denied, 434 U.S. 1038 (1978). The "unconscionable breakdown" concept was utilized by the Third Circuit in Boyd v. Mintz, 631 F.2d 247 (3rd Cir. 1980), to require habeas review where the state courts denied a motion to suppress because it was filed fourteen days late and was not accompanied by a formal application to enlarge the time for filing. Id. at 248. The public defender had agreed to represent the defendant with only two days remaining in the 30-day period in which to file motions to suppress. He omitted to file a formal motion to extend the time for filing in reliance upon a local practice permitting such motions to be argued on the return date of the motion to suppress without previous formal application having been made. Unknown to counsel, however, this practice had been superseded by a new, unwritten policy requiring formal applications. Id. at 248-49. In these circumstances, the court of appeals concluded that "a breakdown in the process [had] occurred" that had denied the defendant "the opportunity to present his fourth amendment claim." Id. at 251.

161. See, e.g., Johnson v. Meacham, 570 F.2d 918 (10th Cir. 1978); O’Berry v. Wainwright, 546 F.2d 1204 (5th Cir.), cert. denied, 433 U.S. 911 (1977).

162. Id.

163. Compare the fifth circuit decisions of O'Berry v. Wainwright, 546 F.2d 1204 (Sth Cir.), cert. denied, 433 U.S. 911 (1977) (independent-and-adequate-state-ground), with Caver v. Alabama, 577 F.2d 1188 (5th Cir. 1978) (corrective-process standard). 
become the victim of a " 'procedural catch-22.' "164 In contrast, another court, presented with similar facts, refused to consider the claim. ${ }^{165}$ In this latter instance, the Fifth Circuit held that Stone precluded federal habeas review "in the absence of allegations that the processes provided by a state to fully and fairly litigate fourth amendment claims are routinely or systematically applied in such a way as to prevent the actual litigation of fourth amendment claims on their merits." 168 Although a procedural breakdown in the opportunity for litigation occurred in each case, the first court viewed "opportunity" from the standpoint of the individual litigant, and the latter considered "opportunity" from the perspective of the state system of fourth amendment adjudication.

In summary, the lower federal courts generally agree that federal habeas corpus review is not available to correct erroneous fourth amendment decisions. When a fourth amendment claim has been rejected on its merits, the habeas inquiry is initially restricted to the adequacy of the process of adjudication. Only when that process is determined to be so deficient as to deny an "opportunity for full and fair litigation" will a habeas court undertake the review of the substantive correctness of the underlying fourth amendment decision. It is also generally accepted that Stone precludes habeas corpus relief when state courts do not reach the merits of a fourth amendment claim because of the defendant's failure to avail himself of state procedures for litigating the claim. Some courts, in limited circumstances, will excuse this failure to utilize available state procedures and will permit habeas corpus review. The majority, however, permit no excuse. Finally, the lower courts agree that Stone does not bar habeas corpus consideration of fourth amendment claims where the state failed to provide procedures for their litigation, or where a breakdown in these procedures occurred. Courts are not, however, in agreement as to the nature of the breakdown that justifies federal collateral review.

\section{B. A Critique of the Process-Substance Distinction}

The lower courts offer no coherent rationale for distinguishing among fourth amendment habeas claims on the basis of whether the alleged error is substantive or procedural. The terms themselves are indefinite even where the reason for drawing the distinction is relatively clear. ${ }^{167}$ Consequently, absent

164. Cruz v. Alexander, 477 F. Supp. 516, 523 (S.D.N.Y. 1979), appeal dismissed, 622 F.2d 573 (2d Cir. 1980). Cruz held that federal collateral review of federal statutory wiretap claims by state prisoners are not affected by Stone and, alternatively, that collateral review was permissible under the Stone exception.

165. Williams v. Brown, 609 F.2d 216 (5th Cir. 1980).

166. Id. at 220.

167. Cf. Hanna v. Plumer, 380 U.S. 460 (1965) (substantive-procedural dichotomy for Erie purposes); Guaranty Trust Co. v. York, 326 U.S. 99 (1945) (same). Cf. generally Ely, The Irrepressible Myth of Erie, 87 Harv. L. Rev. 693 (1974); Changes, Some Further Last Words on Erie, the Bead Game, 87 Harv. L. Rev. 741 (1974); Ely, Some Further Last Words on Erie, the Necklace, 87 Harv. L. Rev. 733 (1974). 
an informing purpose, judicial categorization of fourth amendment claims as either substantive or procedural is likely to be extremely uncertain.

The distinction between substance and process is not clear, even in the paradigmatic case of United States ex rel. Petillo $v$. New Jersey. ${ }^{168}$ This case has been used by lower courts to illustrate the type of defect in state process which warrants habeas review under the "opportunity for full and fair litigation" standard. ${ }^{169}$ In the face of a definitive United States Supreme Court precedent to the contrary, the New Jersey Supreme Court announced a rule in State $v$. Petillo ${ }^{170}$ that precluded challenges to the truthfulness of allegations in affidavits submitted in support of a search warrant. Subsequently, a state criminal defendant moved to suppress evidence, claiming wrongful seizure under the authority of a search warrant procured through police perjury. The state courts, relying upon the Petillo rule, denied his motion without affording him a hearing on the veracity of the underlying affidavit, despite a strong preliminary showing of police perjury. ${ }^{171}$ According to the analysis of some lower courts, ${ }^{172}$ habeas corpus review would be appropriate here since the state failed to provide corrective procedures for litigating the fourth amendment claim. ${ }^{173}$ The error could be classified as procedural on the view that the refusal to hear the claim constituted judicial door-closing tantamount to the failure of the state legislature to enact suppression procedures for such claims. A substantive classification, however, is equally plausible: the error could be taken to represent a misconception of the fourth amendment standard governing the effect of police perjury on the validity of a warrant.

The substantive-procedural dichotomy is further called into question if the above facts are modified slightly to make the error appear more substantive. For instance, in lieu of denying the perjury claim without a hearing, suppose that the trial court holds a hearing on the truthfulness of the facts set forth in the affidavit, and finds that the affidavit is materially perjurious. The court, nevertheless, denies the motion to suppress because a state rule requires an affidavit to be judged on its face in determining its sufficiency to establish probable cause. Most lower federal courts would classify the application of an erroneous fourth amendment standard as substantive and would therefore bar habeas corpus review. ${ }^{174}$ There is, however, no apparent reason why the

168. 418 F. Supp. 686 (D.N.J. 1976), rev'd on other grounds, 562 F.2d 903 (3rd Cir. 1977).

169. The so-called "Petillo rule," see State v. Petillo, 61 N.J. 165, 173, 293 A.2d 649, 653 (1972), cert. denied, 410 U.S. 945 (1973), was not reviewed by the Third Circuit, 562 F.2d at 905 n.3, but has been cited in Gates v. Henderson, 568 F.2d 830 (2d Cir. 1977) (rehearing en banc), cert. denied, 434 U.S. 1038 (1978), for the proposition: "If the state provides no corrective procedures at all to redress Fourth Amendment violations, federal habeas corpus remains available." Id. at 840 .

170. 61 N.J. 165, 173, 293 A.2d 649, 653 (1972), cert. denied, 410 U.S. 945 (1973).

171. Albanese v. State, No. A 298971 (N.J. Super. Ct., Ap. Div. 1973), certif. denied, 64 N.J. 312, 315 A.2d 401 (1973).

172. See notes $159-60$ and accompanying text supra.

173. See United States ex rel. Petillo v. New Jersey, 418 F. Supp. 686, 688-89 (D.N.J. 1976), rev'd on other grounds, 562 F.2d 903 (3rd Cir. 1977); note 169 supra. Cf. generally Gates v. Henderson, 568 F.2d 830, 840 (2d. Cir. 1977) (rehearing en banc), cert. denied, 434 U.S. 1038 (1978).

174. See text accompanying notes 117-24 supra. 
availability of habeas corpus review in these two cases should turn on whether or not a hearing was held prior to denial of the claim.

The decision of the Second Circuit in Kahn v. Flood ${ }^{175}$ further illustrates the mutable nature of the distinction between procedural and substantive error when used to implement Stone's exception. Habeas applicants challenged a search warrant, contending that the affidavit submitted in its support contained material misstatements based on lies told to the affiant by his informant. ${ }^{176}$ The Kahn petitioners claimed that habeas review was permissible under the Stone exception because the state court had refused to hear evidence relevant to the truthfulness of the information supplied by the informant. ${ }^{177}$ The district court denied relief. The Second Circuit determined that false statements of an informant contained in an affidavit would not invalidate a warrant under either the state or federal rules. It affirmed the denial of habeas relief on the basis of Stone.

Since there is no difference between the state and federal rules on this point, petitioners have failed to demonstrate that the New York courts afforded them anything less than a full and fair hearing on their Fourth Amendment claim. Stone v. Powell ... thus bars this attempt to relitigate that claim in a federal forum. ${ }^{178}$

Why the Kahn court evaluated the correctness of the state rule is not entirely clear. Apparently, once the court classified the petitioner's claim of an erroneous evidentiary limitation as procedural, such an inquiry was demanded. A substantive classification would not have triggered an inquiry into the merits of the rule. ${ }^{179}$ This procedural classification is questionable, however, if the essence of the claim involved is viewed as an attack on the state courts' interpretation and application of a fourth amendment rule governing primary police conduct. Surely, habeas applicants should not be able to avoid the impediment of Stone merely by couching substantive claims in terms of erroneous evidentiary limitations. On the other hand, it may well be that the court actually viewed the essence of the claim as procedural, since it related to the judicial process for obtaining search warrants. This reading, if accurate, only further demonstrates the tenuousness of the substantive-procedural distinction. It may be recalled that the circuit court in Wolff, Stone's companion case, granted habeas relief on the same type of claim-the improper issuance of a search warrant-and the Supreme Court reversed without any inquiry into the merits. ${ }^{180}$

More basically, the lower courts do not present any underlying purpose for making the distinction between substance and process. The distinction is clearly irrelevant to the thesis, to be advanced in the next part, that limited

175. 550 F.2d 784 (2d Cir. 1977).

176. Id. at 784 .

177. Id. at 784-85.

178. Id. at 786 .

179. See text accompanying notes $182-83$ supra.

180. See text accompanying notes 13-16 supra. 
fourth amendment habeas review is justified by the need for federal oversight to ensure that the states and their courts satisfy their constitutional obligation to protect the collective fourth amendment rights of their citizens. There is no reason to assume that a procedural, as opposed to a substantive, error indicates a failure to meet this obligation. Neither is there reason to assume the converse.

\section{A Theory of Limited Habeas CoRpus Review of FOURTh AMENDMENT EXCLUSIONARY RULE CIATMS}

As we have seen, the Stone majority opinion rests on three essential propositions: the primary purpose of the exclusionary rule is police deterrence, the accused does not have a personal constitutional right to application of the rule, and the deterrent benefits attainable from the rule's application in collateral proceedings are outweighed by the attendant social costs. ${ }^{181}$ These propositions are defensible. But stated without qualification and taken seriously, they imply a complete ban on habeas consideration of exclusionary rule claims. ${ }^{182}$ Stone, however, by creating an exception to its ban on habeas review, implicitly qualified this trilogy of premises. The ban imposed on application of the exclusionary rule in federal collateral proceedings must be reconciled with the Court's explicit reaffirmation of the rule's binding effect in state court proceedings and on direct review in the Supreme Court. ${ }^{183}$ Since the general rule in Stone barring federal habeas corpus review rests on a construction of the fourth amendment (as incorporated in the fourteenth), ${ }^{184}$ the exception and the different treatment of the rule on direct review presumably must also be rooted in the Constitution. Accordingly, this part of the Article suggests a theory of the fourth amendment that reconciles this differential treatment ${ }^{185}$ and justifies the Stone exception.

181. See text accompanying notes $27-92$ supra.

182. A state prisoner is entitled to habeas corpus relief if he is "in custody in violation of the Constitution." 28 U.S.C. § 2254(a) (1976). Stone holds that a person whose conviction is based upon the admission of illegally seized evidence is not entitled to collateral relief; his constitutional rights were not violated by use of such evidence and, therefore, his custody is not unconstitutional. 428 U.S. at 482 . Accordingly, it should make no constitutional difference whether or not a defendant received a full and fair opportunity to litigate his exclusion claim. Nevertheless, Stone permits habeas corpus review where this opportunity has been denied.

183. 428 U.S. at $479-82,486$.

184. For example, Stone explicitly held that "the Constitution does not require" the granting of federal habeas corpus relief to a state prisoner convicted on the basis of the admission of illegally seized evidence. Id. at 482 .

185. Some commentators have suggested that constitutional grounds cannot explain Stone's different treatment of exclusionary rule claims on direct versus collateral review. To these commentators, the different treatment represents judicial rewriting of the habeas corpus statute, which the Court refused to acknowledge. See, e.g., Tushnet, Constitutional and Statutory Analyses in the Law of Federal Jurisdiction, 25 U.C.L.A. L. Rev. 1301, 1316-18 (1978). I have chosen instead to take the Court at its word, in the hope that this course will lead to the elucidation of a coherent rationale employable in future cases. 


\section{A. The Differential Treatment of Exclusionary Rule Claims on Collateral Review}

In his Stone dissent, Justice Brennan argues that the disparity in the majority's treatment of exclusionary rule claims on direct versus collateral review is constitutionally unsupportable. ${ }^{188}$ According to his reasoning, until Mapp v. Ohio ${ }^{187}$ is overruled, constitutional error occurs whenever evidence that has been obtained in violation of the fourth amendment is introduced at trial. ${ }^{188}$ If the error is not corrected on appeal, he finds no logic to support a view that it "suddenly dissipates" when raised in a habeas corpus action. ${ }^{180}$ This criticism, however, refuses to accept the Court's proposition that the exclusionary rule is a judge-made remedy designed to deter police violations of the fourth amendment, and not a personal constitutional right of the accused. Given that proposition, a person convicted on the basis of illegally seized evidence has not suffered an unconstitutional conviction and, consequently, is not being held in "custody in violation of the Constitution" within the meaning of the habeas corpus statute. ${ }^{180}$ From the defendant's perspective, the constitutional error did not suddenly vanish when raised collaterally; it never existed. ${ }^{191}$

Constitutional error is absent, according to the Court, because application of the exclusionary rule comes too late to prevent constitutional injury, which occurs at the time of the illegal search or seizure. ${ }^{192}$ Further, exclusion does not provide compensatory redress to victims of illegal searches and seizures. The benefits accrue to a select class of victims, i.e., persons charged with crime, and, however calculated, the benefits are not proportionate or responsive to the underlying constitutional injury. ${ }^{193}$ This reasoning, however, casts doubt on the Court's constitutional authority to impose the exclusionary rule on state court proceedings: if the exclusionary rule does not

186. 428 U.S. at 502-06 \& 510 n.9 (Brennan, J., dissenting).

187. 367 U.S. 643 (1961).

188. 428 U.S. at 509 (Brennan, J., dissenting).

189. Id. at 509-10 (Brennan, J., dissenting).

190. 28 U.S.C. $\S 2254$ (a) (1976).

191. Justice Brennan also questions whether the facts support the discrimination between direct and collateral review. Seizing upon an intimation by the majority that the diminution in deterrent effect of the exclusionary rule on collateral review is in part due to the usually lengthy interval between the alleged police misconduct and collateral review, he maintains that "it is difficult to see how the Court could constitutionalize any such asserted temporal distinctions, particularly in light of the differential speed with which criminal cases proceed even on direct appeal." 428 U.S. at 509 n.8 (Brennan, J., dissenting). Conceding the accuracy of this observation, however, does not substantially dilute the force of the Court's principal factual contention, which was that the deterrent effect of collateral review is negligible because the police will not fear that a federal habeas court will uncover an illegal search or seizure that went undetected at trial or on appeal.

192. As Justice Powell observed, exclusion "is not calculated to redress the injury to the privacy of the victim of the search or seizure, for any "[r]eparation comes too late." " 428 U.S. at 486 (quoting Linkletter v. Walker, 381 U.S. 618, 637 (1965)).

193. In the Court's cost-benefit analysis, Justice Powell stated that "[t]he disparity in particular cases between the error committed by the police officer and the windfall afforded a guilty defendant by application of the [exclusionary] rule is contrary to the idea of proportionality that is essential to the concept of justice." 428 U.S. at 490. 
prevent or repair constitutional harm to the accused, what then is the source of the Court's power to require state adherence to the rule? ${ }^{194}$

The explanation is to be found in the Court's two-tier view of the fourth amendment. On the one hand, the amendment assures to each individual a right to be free from unreasonable searches and seizures. Accordingly, the Court held in Bivens v. Six Unknown Named Agents of Federal Bureau of Narcotics ${ }^{195}$ that the victim of a fourth amendment violation by federal officers has a cause of action under the amendment for damages against the persons responsible. Furthermore, this action is maintainable without regard to the deterrent effect of such damage actions on future police misconduct. ${ }^{196}$ The remedy is instead intended to provide compensation for injuries suffered as a result of unconstitutional conduct. ${ }^{197}$ On the other hand, the fourth amendment also commands government to regulate law enforcement activities in a manner protective of the people's collective security against unreasonable searches and seizures. ${ }^{198}$

The Stone Court interprets the ruling in Mapp, which made the exclusionary rule binding upon the states, as an outgrowth of this latter command. The states are constitutionally obligated to take measures designed to protect the collective fourth amendment rights of their citizens. Otherwise, if nothing is done, the police, in their zeal to apprehend suspected criminals, will ignore the commands of the fourth amendment to such a degree as to render meaningless the guarantee of collective security. ${ }^{199}$ Exclusion is one effective means to obtain police respect for the fourth amendment rights of the people, and it may be the only effective means available to a court. Although suppression of evidence on fourth amendment grounds often provides a windfall for a criminal defendant, enabling him to escape a deserved conviction, this is thought necessary to motivate him, and others similarly situated, to bring to light and to deter unconstitutional police conduct. Operation of the exclusionary rule places the criminal defendant in the role of private attorney general, acting to vindicate the fourth amendment rights of all.

The Constitution does not require the exclusionary rule, as opposed to some alternative method, to implement the fourth amendment's guarantee of collective security. What is required is "something that works" 200 to effectu-

194. The Supreme Court, of course, possesses no supervisory power over the state courts. See Mapp v. Ohio, 367 U.S. 643, 678 (1961) (Harlan, J., dissenting). Consequently, its authority to impose the exclusionary rule on the states must be derived from a constitutional source. In contrast, the Court's authority to restrict the admission of evidence in federal prosecutions is not circumscribed by this constraint. See, e.g., McNabb v. United States, 318 U.S. 332 (1943). See generally Hill, The Bill of Rights and the Supervisory Power, 69 Colum. L. Rev. 181 (1969).

195. 403 U.S. 388 (1971).

196. Id. at 395-97. The Court in Bivens reasoned that the victim's right to receive compensation for the injury to his privacy interests is independent from the incidental consequences of according monetary relief. Id. Cf. generally id. at 407-08 (Harlan, J., concurring); Schrock \& Welsh, Reconsidering the Constitutional Common Law, 91 Harv, L. Rev. 1117, 1135-38 (1978).

197. 403 U.S. at 395-97. (1974).

198. See Amsterdam, Perspectives on the Fourth Amendment, 58 Minn. L. Rev. 349, 367-72

199. Id. at 433.

200. Kaplan, The Limits of the Exclusionary Rule, 26 Stan. L. Rev. 1027, 1030 (1974). See generally Monaghan, supra note 68 , at $1-10$. 
ate fourth amendment values, whether created by the courts or another branch of government, and there is considerable flexibility regarding the manner of operation of the mechanism selected. Since the exclusionary rule constitutes a prophylactic measure, rather than a delineation of a constitutional right, the Court may withhold enforcement of the rule on habeas corpus, while continuing to enforce it against the states on direct appeal, because of a prudential judgment about the relative utility of the rule's application in these contexts.

\section{B. Justification of the Exception}

When the basis of Stone is understood as a utilitarian judgment about the enforcement of collective fourth amendment rights, why should it make a constitutional difference in the context of habeas corpus review whether a state has or has not provided an "opportunity for full and fair litigation"? Permitting collateral review in this circumstance cannot be traced to any personal constitutional right of the accused. A state could refuse entirely to permit defendants to challenge prosecutorial evidence on fourth amendment grounds without transgressing upon their personal constitutional rights. ${ }^{201}$ Neither is the exception explainable on the basis of police deterrence. Stone asserts that postconviction review has negligible deterrent effect, because the police will not fear that a previously undetected fourth amendment violation will be disclosed in collateral proceedings. ${ }^{202}$ If this assumption about police psychology is correct, then, as Justice Brennan points out, it follows that the police will not fear that "habeas review might reveal that the state courts had denied the defendant an opportunity to have a full and fair hearing on his claim." 203

There is, however, an alternative hypothesis to elucidate the exception. Prior to Stone, habeas corpus review of fourth amendment exclusionary rule claims was routinely available. The practice was discontinued by the Court for two reasons: (1) exclusion is not a personal constitutional right of the accused, and (2) application of the exclusionary rule by state judges at trial and on appeal is adequate to achieve the rule's deterrent objective. ${ }^{204}$ The Stone Court may have deemed routine habeas corpus review of state fourth amendment decisions inadvisable, given that state court adjudication of fourth amendment issues is presently adequate. It does not follow, however, that federal collateral review of exclusionary rule claims should be foreclosed entirely. Such review should remain available, where necessary, to ensure that states and their courts continue to meet their constitutional responsibility to safeguard collective fourth amendment rights. While direct review in the Supreme Court may be sufficient to elaborate fourth amendment doctrine, it is inadequate for this regulatory purpose..$^{205}$

201. The state would, nevertheless, have a constitutional obligation to implement collective fourth amendment rights by other means.

202. See notes 75-79 and accompanying text supra.

203. 428 U.S. at 514 (Brennan, J., dissenting).

204. See notes 80-84 and accompanying text supra.

205. See text accompanying notes $80-92$ supra. 
Accordingly, the Stone exception should be construed as providing the lower federal courts with leverage to ensure adequate implementation by the states of the fourth amendment protections. Depending on how the exception is defined, this interpretation is not inconsistent with the Court's expression of confidence in the good faith and intellectual ability of state judges to decide search and seizure claims. ${ }^{206}$ These judicial attributes are not relevant where state legislatures do not enact or repeal procedures for raising and litigating fourth amendment suppression motions. Thus, there would be no inconsistency if the inquiry of the habeas courts under the exception were limited to whether the state provided procedures to raise and litigate the suppression claims.

It is not necessary, however, to construe the exception so narrowly. It is well to remember that the Court's confidence in state judges is based on their record of fourth amendment adjudication under a system where "the threat of habeas serve[d] as a[n] . . . additional incentive for trial and appellate courts throughout the land to conduct their proceedings in a manner consistent with established constitutional standards." ${ }^{207}$ Consequently, one may concede the inadvisability of having federal collateral review available for every state court denial of a fourth amendment claim, without conceding to the imposition of a nearly absolute ban on such review. What is needed is an interpretation of the exception that gives the federal courts limited authority to intervene through habeas corpus in order to ensure the adequate protection of collective fourth amendment rights.

\section{A Proposal for Defining the Scope of Fourth AMENDMent Habeas CoRpus ReVIEW}

Critical to the selection of a rule governing the cognizability of fourth amendment exclusion claims is the effect of that rule on the implementation of collective fourth amendment rights. Accordingly, habeas corpus relief should be available under Stone's exception to correct judicial errors which, if otherwise uncorrected, could lead to diminished police adherence to fourth amendment values and a consequential loss of collective security. These errors may be termed "systemic," in that their occurrence is, or is likely to become, widespread among the courts of a particular state. An apt illustration is where a state's highest court has announced an erroneous and fertile fourth amendment rule of decision.

Habeas corpus review of fourth amendment errors by state courts of a systemic nature is necessary because such errors will tend to legitmate unconstitutional actions in the eyes of law enforcement and thus increase their incidence. ${ }^{208}$ In some cases, an erroneous judicial decision will directly and

206. See note 82 and accompanying text supra.

207. Desist v. United States, 394 U.S. 244, 262-63 (1969) (Harlan, J., dissenting).

208. Judicial exclusion of unlawfully seized evidence authoritatively disavows the unconstitutional conduct and reaffirms the values of the fourth amendment. See, e.g., J. Feinberg, Doing 
immediately effect the propagation of unconstitutional police action. For example, suppose a state supreme court interprets a state statute as authorizing random stops of motorists to check drivers' licenses and vehicle registrations. The court further holds that the statute is consistent with the fourth amendment, and affirms a conviction for possession of illegal drugs discovered incident to a random stop under the statute. ${ }^{209}$ If the fourth amendment decision is erroneous, every motorist and passenger in the state is threatened with an "unreasonable seizure." Consequently, habeas review is appropriate given the significant impact of the decision on the privacy interest of so many persons.

It is not necessary that the impact on collective security be as immediate or as broad as that illustrated in the previous case to justify the availability of habeas review. Nevertheless, not every erroneous fourth amendment decision by a state court is likely to have systemic consequences. For instance, an erroneous application of fourth amendment principles by a state trial court should ordinarily not be subject to habeas review unless there is some reason to believe that the error would have a meaningful effect on future judicial decisions or the conduct of the police. Even an erroneous fourth amendment decision by a state's highest court in a reported decision is not necessarily systemic, since it may have virtually no precedential significance, e.g., where the rule of decision is limited to unique facts unlikely to recur.

When presented with a fourth amendment claim, a federal habeas court should first ask if the alleged error is systemic. If the answer is negative, the court should deny relief. If the answer is affirmative, the court should decide

and Deserving 101-04 (1970). The converse is also true, as Chief Justice Warren observed in Terry v. Ohio, 392 U.S. I (1968). "A ruling admitting evidence in a criminal trial . . . has the necessary effect of legitimizing the conduct which produced the evidence. ..." Id. at 13. Moreover, empirical evidence supports the proposition that law enforcement officials perceive exclusion of evidence as the embodiment of the guarantee against unreasonable searches and seizures. See Kamisar, Is the Exclusionary Rule an 'Illogical' or 'Unnatural' Interpretation of the Fourth Amendment?, 62 Jud. 66, 69-73 (1978).

209. The Nebraska Supreme Court reached this conclusion on these facts in State v. Holmberg, 194 Neb. 337, 231 N.W.2d 672 (1975). Although the district court granted habeas corpus relief, the Eighth Circuit reversed and reasoned that Stone precluded the federal courts from reaching the merits. Holmberg v. Parratt, 548 F.2d 745 (8th Cir.), cert. denied, 431 U.S. 969 (1977).

210. Judge Bright dissented in the Holmberg decision and urged review of the merits of the fourth amendment issue, since the case presented "important and unsettled constitutional issues" that had not received federal review. 548 F.2d at 749 (Bright, J., dissenting). He further contended that Stone did not preclude federal collateral review, because

the constitutional issue here is not whether, on a particular set of facts, a police officer

... invaded an individual's fourth amendment rights for here the police officer acted

pursuant to a general state policy enacted by statute.

-...

In a sense, [petitioner] represents every motorist travelling the highways of this Nation.

The authority which Nebraska claims for its highway patrolmen threatens everyone's

freedom of movement in a motor vehicle.

Id. at 748-49 (Bright, J., dissenting). The Supreme Court subsequently held unconstitutional such discretionary random stops to check driver's license and vehicle registration. Delaware v. Prouse, 440 U.S. 648 (1979). 
the merits of the claim. In most instances, federal judges will be able to determine this question based on an examination of the pleadings and any state court opinions rendered in the case. If a habeas petitioner claims that the error in his case is systemic because of its frequent occurrence in state judicial decisions, the respondent should have the burden of demonstrating otherwise.

The suggested approach does not require federal courts to define the minimal level of fourth amendment implementation permissible under the Constitution, nor to measure the level of police compliance with fourth amendment dictates. These determinations probably cannot be made. Moreover, courts are able to act without them, as evidenced by the extreme roughness of the cost-benefit calculus used by the Court in Stone to differentiate between application of the exclusionary rule on direct versus collateral review, ${ }^{211}$ and by the imprecision of the Court's standard for implementing Stone's exception. ${ }^{212}$

The focus on systemic error also clarifies the appropriate disposition of fourth amendment claims that are not litigated on the merits in state court. When state courts do not decide a fourth amendment claim because of procedural defaults attributable to the defendant, some habeas courts have advocated use of the "cause and prejudice" standard to determine whether the default should be excused. ${ }^{213}$ Other courts have barred collateral review without regard to either the reason for or prejudicial effect of the forfeiture, so long as state processes for the adjudication of fourth amendment claims, including rules of procedural forfeiture, afforded a reasonable opportunity for litigation. ${ }^{214}$ Since the corrective-process approach concentrates on the system of exclusionary rule enforcement, while the "cause and prejudice" standard bears upon the circumstances of a particular litigant, the former approach is the appropriate one in cases of the defendant's procedural default.

The state courts' failure to decide the merits is not always attributable to the defendant, e.g., when a fourth amendment claim is not decided because of judicial oversight..215 In this circumstance, some courts have granted habeas corpus review since the particular defendant was denied an opportunity to litigate. ${ }^{216}$ Other courts, however, have denied collateral review unless the judicial error that prevented actual litigation of the claim occurred "routinely or systematically." 217 The latter approach is preferable because of its systemic focus.

The doctrinal justification of Stone advanced here provides a basis for interpretation of the exception. ${ }^{218}$ Nevertheless, Stone is difficult to rational-

211. See notes $75-92$ and accompanying text supra.

212. See notes 93-115 and accompanying text supra.

213. See notes $154-58$ and accompanying text supra.

214. See notes 159-63 and accompanying text supra.

215. See notes 164-66 and accompanying text supra.

216. See, e.g., note 164 supra.

217. See notes $165-66$ and accompanying text supra.

218. It is also consistent with the Court's holdings as to non-fourth amendment claims. See notes 224-50 and accompanying text infra. 
ize fully, primarily for the reasons suggested in a hypothetical posed by Justice White in dissent. ${ }^{219}$ Two confederates are separately tried for a state crime and convicted on the same evidence. Both raise identical claims that essential prosecution evidence was seized in violation of their fourth amendment rights, and these claims are rejected by the state courts after careful consideration. One of these individuals is denied Supreme Court review of his conviction. The other obtains Supreme Court review and a reversal of his conviction based on the application of established fourth amendment law to undisputed facts. The state has no case without the excluded evidence, so he goes free. The first then petitions for habeas corpus, contending that his fourth amendment claim was erroneously decided, citing the Supreme Court's decision in his accomplice's case. The petition is dismissed on the basis of Stone.

Acceptance of the validity of Stone's underlying propositions-that exclusion is not a personal right of the accused, that judicial remedies may be appropriately afforded to litigants for purposes of realizing social goals rather than personal justice, and that uneven treatment of exclusion claims on direct as opposed to collateral review has a rational basis-however, does not produce comfortable acceptance of the outcome in the hypothetical. Equal treatment of similarly situated individuals is a core value of our conventional morality, and for courts to act in a manner contrary to this value, albeit in rational pursuit of desirable social goals, tends to weaken this value and makes us uneasy. We too could fall victim to unequal treatment at the hands of the courts in the pursuit of the general good. This adverse impact does not figure in the Court's cost-benefit analysis, perhaps because any weight assigned would be arbitrary or, more fundamentally, because equal treatment of persons is a principle not readily subject to defeasance on instrumental grounds in our legál culture.

\section{FURTHER IMPLICATIONS OF STONE}

\section{A. Enforcement of the Exclusionary Rule Against the States}

Notwithstanding Stone's reaffirmation of the binding effect of the exclusionary rule on the states, two factors pose questions for the continued imposition of the exclusionary rule upon the states: the Stone Court's rejection of the personal constitutional right rationale in favor of deterrence, and the Court's balancing analysis. A hypothetical illustrates these issues. Suppose a police department establishes a program of internal education, regulation, and sanctions, designed to induce adherence to fourth amendment limitations on police conduct. Despite the program, however, an officer engages in an unconstitutional search and discovers evidence of criminal conduct by the victim of the fourth amendment violation. Over the defendant's objection, the state courts permit reliance on this evidence for conviction, using the rationale 
that the accused has no personal right to exclude the evidence and that the departmental program is an adequate substitute for the exclusionary rule.

What is the appropriate standard for determining the adequacy of the departmental program? One approach would require the state to demonstrate that the departmental program is as effective as or more effective than the exclusionary rule in maintaining police conformity with the dictates of the fourth amendment. The constitutional logic for this position would be that the fourth amendment requires government to offer a minimum level of practical protection for fourth amendment guarantees, i.e., that attainable through use of the exclusionary rule. A comparison of the deterrent effectiveness of the two regimes, however, is probably not possible because of difficulties in data collection. ${ }^{220}$

Now assume that the state concedes that the departmental program is a less effective deterrent than exclusion. It is by no means clear that a majority of the current Court would demand continued adherence to the exclusionary rule in this circumstance. Stone's balancing analysis teaches that comparative costs as well as benefits are relevant in determining the utility and, thus, the necessity of the exclusionary rule in various fora. ${ }^{221}$ The logic also dictates that comparative costs are relevant to determining if a particular mechanism is an adequate replacement for the exclusionary rule. Accordingly, the greater likelihood is that the Court would accept the police program as an adequate substitute for the exclusionary rule on a plausible showing that the former exacts less social cost than the latter, and that this reduction offsets the former's diminished deterrent effectiveness.

A deterrent mechanism must presumably achieve some minimum level of police conformity with fourth amendment values in order to satisfy the threshold of fourth amendment implementation. If zero social cost could offset zero deterrent benefit, the Stone majority would not have reaffirmed the continued enforcement of the exclusionary rule against the states. The intuitive and rough calculus endorsed by the Court as a basis for differentiating between application of the exclusionary rule on collateral review, as opposed to at trial and on direct review, would appear, however, to leave considerable discretion to the states to devise alternatives to, or modifications of, the exclusionary rule. 222 Less effective measures involving lower social cost may well satisfy the Court's constitutional balance point. Indeed, it appears that a majority of the Stone Court would accept almost any good faith effort on the part of the states to find a substitute for the exclusionary rule. ${ }^{223}$

220. See Oaks, supra note 77 , at $712-16$.

221. See text accompanying notes $75-92$ supra.

222. For a discussion of alternatives, and modifications of the exclusionary rule, see Geller, Enforcing the Fourth Amendment: The Exclusionary Rule and Its Alternatives, 1975 Wash. U.L.Q. 621, 689-722.

223. One factor militating against abandonment of the exclusionary rule, until an alternative deterrent mechanism is implemented, is the concern that this might be misinterpreted by the police as an implicit repeal of the prohibition against unreasonable searches and seizures. Chief Justice Burger, one of the rule's harshest critics, has observed that "the public interest would be poorly 


\section{B. Habeas Corpus Litigation of Non-Fourth Amendment Claims}

1. Claims unrelated to guilt or innocence. Some have asserted that Stone presages a revisionist movement, led by Justice Powell, to limit the substantive scope of federal habeas corpus jurisdiction to claims bearing upon the integrity of the factfinding process underlying a conviction. ${ }^{224}$ According to this interpretation, the fundamental principle of Stone is stated in footnote 31 of

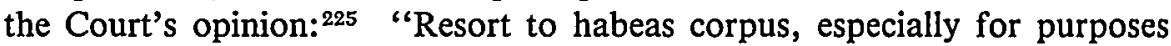
other than to assure that no innocent person suffers an unconstitutional loss of liberty, results in serious intrusions on values important to our system of government." 226 Justice Powell vigorously supported this principle in his earlier concurring opinion in Schneckloth $v$. Bustamonte, ${ }^{227}$ in which he was joined by Chief Justice Burger and Justice Rehnquist in urging that the central role of the habeas corpus remedy is to ensure that "no innocent man suffers an unconstitutional loss of liberty." 228 Acceptance of this reasoning leads to the withdrawal of habeas corpus relief for claims unrelated to the reliability of the guilt-determination process.

Although Stone reached the result advocated by Justice Powell in Schneckloth, ${ }^{229}$ the Court in Stone did not lay the groundwork for an abridgement of the substantive scope of habeas corpus jurisdiction based upon a guilt-determinative threshold. As noted, Stone rests on judgments regarding the justification and utility of the exclusionary rule, rather than on the kind of revisionist interpretation of the substantive scope of habeas corpus advocated

served if law enforcement officials were suddenly to gain the impression, however erroneous, that all constitutional restraints on police had somehow been removed-that an open season on criminals had been declared." Bivens v. Six Unknown Named Agents of Fed. Bureau of Narcotics, 403 U.S. 388, 421 (1971) (Burger, C.J., dissenting).

224. See Rose v. Mitchell, 443 U.S. 545, 583-84 n.16 (1979) (Powell, J., concurring); note 4 supra.

225. Cover \& Aleinikoff, note 4 supra, at 1086.

226. 428 U.S. at 491 n.31.

227. 412 U.S. 218, 256-58 (1973) (Powell, J., concurring). For instance, Justice Powell wrote: "That federal courts would actually redetermine constitutional claims bearing no relation to the prisoner's innocence with the possibility of releasing him from custody if [a] search is held unlawful not only defeats our societal interest in a rational legal system but serves no compensating ends of personal justice." Id. at 258 (Powell, J., concurring). This view had been advocated earlier by Justice Black in his dissent in Kaufman v. United States, 394 U.S. 217, 231-42 (1969) (Black, J., dissenting), where he rejected the court's holding that federal prisoners could raise fourth amendment claims in collateral proceedings.

I would not let any criminal conviction become invulnerable to collateral attack where there is left remaining the probability or possibility that constitutional commands related to the integrity of the fact-finding process have been violated. In such situations society has failed to perform its obligation to prove beyond a reasonable doubt that the defendant committed the crime.

Id. at 241 (Black, J., dissenting).

228. 412 U.S. at 256 (Powell, J., concurring).

229. In his Schneckloth concurrence, Justice Powell advocated that "the inquiry of the federal court on habeas review of a state prisoner's Fourth Amendment claim should be confined solely to the question whether the defendant was provided a fair opportunity in the state courts to raise and have adjudicated the Fourth Amendment claim." Id. at 266 (Powell, J., concurring). 
by Justice Powell's Schneckloth concurrence. ${ }^{230}$ The detrimental effect of exclusion on the factfinding process, to be sure, was a factor in the utilitarian balance. It was not, however, the fundamental premise of the decision. ${ }^{231}$ The Stone Court stated that its decision "is not concerned with the scope of the habeas corpus statute as authority for litigating constitutional claims generally." 232

The Court's subsequent decision in Rose $v$. Mitchell ${ }^{233}$ provides further evidence that a majority of the Court is unwilling to rewrite the habeas corpus statute to conform to the view expressed by Justice Powell in Schneckloth. A question addressed in Rose was whether Stone "should be extended so as to foreclose a grant of federal habeas corpus relief to a state prisoner on the ground of discrimination in the selection of the grand jury."234 The composition of the petit jury was not challenged, nor was any other claim raised which affected the reliability of the guilt determination. Consequently, it was argued that Stone's logic precluded habeas corpus relief. The Rose Court rejected this extension of Stone explaining that the ruling in Stone was confined "to cases involving the judicially created exclusionary rule." ${ }^{235}$ Significantly, Justice

230. Justice Powell's opinion for the Court in Stone contrasts markedly with his earlier concurring opinion in Schneckloth. In Schneckloth, Justice Powell drew primarily upon the views of Judge Friendly and Professor Bator and urged that the Court's interpretation of the substantive scope of the writ of habeas corpus in Brown v. Allen, 344 U.S. 443 (1953), was overbroad. There, the Court indicated that habeas jurisdiction encompassed constitutional claims generally. See Friendly, Is Innocence Irrelevant? Collateral Attack on Criminal Judgments, 38 U. Chi. L. Rev. 142 (1970); note 110 supra.

Professor Bator's thesis is that the Court's decision in Brown v. Allen marked a radical departure from precedent without any historical or policy justification. Emphasizing the importance of finality in criminal proceedings and stressing that no legal system can ever determine a defendant's guilt or innocence with absolute certainty, Bator argues that judicial inquiry on a writ of habeas corpus should be limited to whether the state provided adequate process for the litigation of the defendant's constitutional claims. See generally Bator, supra note 108. Judge Friendly urges a reduction in the substantive scope of the writ for different reasons, i.e., that the writ, historically, was intended to remedy unjust confinement. Accordingly, he advocates the limitation of cognizable claims on federal habeas corpus to those affecting the reliability of the guilt determination in the particular conviction under attack, and would exclude fourth amendment suppression claims. See generally Friendly, supra.

Justice Powell's analysis in Schneckloth reflects an amalgamation of these two views. Collateral litigation of fourth amendment claims is felt undesirable because it does not affect the reliability of the guilt-determination process (Friendly's thesis). Nevertheless, fourth amendment claims should be cognizable where the state does not provide an opportunity for their full and fair litigation (Bator's thesis).

The concerns of Bator and Friendly also appear in Stone's balancing analysis. One of the additional costs of applying the exclusionary rule collaterally is impairment of the value of "finality in criminal trials." 428 U.S. at 491 n.31. One of the costs of applying the rule at any juncture is the diversion of the criminal proceeding from the ultimate question of guilt or innocence, and the loss of typically reliable evidence if suppression is granted. Id. at 490 .

231. It has been suggested that Justice Powell's shift in emphasis from the guilt-determinative threshold in Schneckloth to the utilitarian analysis of the exclusionary rule in Stone was necessary to attract a majority of the Court. See Boyze, Federal Habeas Corpus After Stone v. Powell: A Remedy Only for the Arguably Innocent?, 11 U. Rich. L.R. 291, 311-15 (1977); Soloff, Litigation and Relitigation: The Uncertain Status of Federal Habeas Corpus for State Prisoners, 6 Hofstra L. Rev. 297, 307-09 (1978).

232. 428 U.S. at 494 n.37 (emphasis in original).

233. 443 U.S. 545 (1979).

234. Id. at 559.

235. Id. at 560 . 
Powell, arguing against habeas corpus consideration of the grand jury claim, relied primarily on his Schneckloth concurrence, rather than on Stone, to support the view that habeas corpus reviews should not be routinely available for claims unrelated to guilt or innocence. ${ }^{238}$

2. Claims founded on prophylactic rules. Stone is not authority for limiting habeas corpus review of non-guilt-related claims. Nevertheless, it does provide a doctrinal basis for curtailing collateral litigation of certain claims which, akin to fourth amendment exclusion, rest on judge-made rules designed to foster constitutionally rooted interests, but which are neither delineations of personal constitutional rights nor indispensable to their protection. Observing that these rules, although derived from constitutional guarantees, are not unalterably essential to their realization, one constitutional commentator describes them as "constitutional common law" to denote the availability of legislative modification and alternatives. ${ }^{237}$ The Mapp $^{238}$ exclusionary rule, the Miranda v. Arizona ${ }^{239}$ mandate of warnings to persons in custody, and the Wade $v$. United States ${ }^{240}$ requirement of the presence of defense counsel at line-ups are within this category of special constitutional rules. The salient characteristic common to all is that they represent a practical and prudential choice permitting of alternatives. The Court has acknowledged that Miranda and Wade are subject to modification or abrogation by alternative mechanisms that facilitate the underlying constitutional interests served by their rulings. ${ }^{241}$ Similarly, the decision in Stone to limit the application of the exclusionary rule on habeas corpus review, while retaining the rule in full force and effect at state trials and on direct review, testifies to its variability.

236. Id. at 583 (Powell, J., concurring). Justice Powell sought to rationalize Stone's emphasis of the point that the exclusionary rule is a judge-made remedy rather than a personal constitutional right with his position in Rose, as follows:

To be sure, in Stone v. Powell . . . we emphasized that the Fourth Amendment exclusionary rule was a "judicially created remedy rather than a personal constitutional right." We did so, however, only in rejecting the suggestion of the dissent that our decision would lead to a "drastic withdrawal of federal habeas jurisdiction" . . . the extent of which might be unlimited. Stone recognized that the Fourth Amendment exclusionary rule was not designed to protect the right of an individual to be free from unjust conviction. Thus, the justification for undermining the finality of state-court judgments that exists in many habeas corpus actions was absent. Properly understood, therefore, the rationale of our decision in Stone is not only consistent with denying collateral relief for claims of unfair indictment, but actually presages such a limitation on habeas corpus.

Id. at $587-88$ n. 10 .

237. Monaghan, supra note 67, at 1-10, 18-26. For a critique of Professor Monaghan's theory of subconstitutional rulemaking by the Court, see Schrock \& Welsh, supra note 29.

238. See Mapp v. Ohio, 367 U.S. 643 (1961).

239. 384 U.S. 436 (1966). See Michigan v. Tucker, 417 U.S. 433 (1974). The Miranda rules effectuate a suspect's privilege against self-incrimination during custodial interrogation.

240. 388 U.S. 218 (1967). The Wade rules guard against suggestive identification procedures and protect a defendant's right to a fair trial.

241. Miranda v. Arizona, 384 U.S. 436, 467 (1966); United States v. Wade, 388 U.S. 218, 239 (1967). 
Conceding that Stone provides a doctrinal basis for limiting or banning habeas review of claims asserted under the Miranda or Wade rule ${ }^{242}$ is not to counsel the wisdom of doing so. The latter judgment requires careful evaluation of the positive and negative effects of the prophylactic rule at issue and the likely consequences of restricting collateral litigation of claims asserted under such rule.

By way of illustration, compare and contrast Miranda with Mapp claims. The Miranda Court prescribed warnings that the police must afford a suspect in custody in order for inculpatory statements obtained through interrogation to be admissible into evidence. Miranda thus couples two prophylactic rules: a procedural safeguard, in the form of required warnings, to effectuate the constitutional guarantee against compelled incrimination; and an exclusionary remedy to enforce the warning requirement. Prior to the Miranda decision, the admissibility of confessions was governed by an elusive due process, voluntariness standard. Under this standard, detailed judicial inquiry into the totality of the circumstances surrounding the obtaining of an inculpatory statement was required to determine both the confession's reliability and the acceptability of the police methods used. ${ }^{243}$ Miranda was predicated on several objectives. First, the police received concrete guidance encouraging self-regulation designed to protect the constitutional rights of suspects and reasonably to ensure the admissibility of confessions properly obtained. Secondly, the lower courts were given easily applicable rules of decision for a broad spectrum of cases. Finally, the Supreme Court was relieved of detailed, case-by-case factual analysis in reviewing confession challenges. In contrast, none of these positive aspects accompanied the decision in Mapp to make the exclusionary rule binding on the states. Mapp only contained a remedial component and did nothing to clarify the very general constitutional prohibition against unreasonable searches and seizures for either the police or the courts.

Not surprisingly, therefore, the balancing of costs and benefits involved in determining if Miranda claims should be fully reviewable on habeas differs significantly from the calculus elaborated in Stone for Mapp claims. ${ }^{244}$ To

242. Chief Justice Burger has advocated the withdrawal of habeas corpus review for Miranda claims because of their prophylactic nature. See Brewer v. Williams, 430 U.S. 387, 42324 (1977) (Burger, C.J., dissenting). The lower federal courts, however, have declined invitations to extend Stone's barrier to Miranda claims. See, e.g., Harryman v. Estelle, 616 F.2d 870 (5th Cir.), cert. denied, 449 U.S. 860 (1980); Patterson v. Warden, 624 F.2d 69 (9th Cir. 1980) (per curiam); Wilson v. Henderson, 584 F.2d 1185, 1189 (2d Cir. 1978), cert. denied, 442 U.S. 945 (1979). But see Richardson v. Stone, 421 F. Supp. 577 (N.D. Cal. 1976), which held as an alternative ground for decision that the petitioner made no claim of innocence and that his Miranda claim did not go to the basic justness of his conviction.

The Chief Justice has also urged that sixth amendment claims not impugning the integrity of factfinding should not be cognizable on habeas review. This stance adopts the position taken in Justice Powell's Schneckloth concurrence that habeas corpus relief should be limited to those claims which affect the reliability of the guilt-determination process. See Brewer v. Williams, 430 U.S. 387, 425-27 (1977) (Burger, C.J., dissenting).

243. See, e.g., Rogers v. Richmond, 365 U.S. 534 (1961).

244. See notes 75-92 and accompanying text supra. 
begin with, the effects of Miranda and Mapp claims on the reliability of guilt determination vary substantially. The exclusion of statements necessitated by a Miranda violation frequently enhances reliability, ${ }^{245}$ while enforcement of the Mapp rule almost never does. ${ }^{248}$ Rather, the latter typically has precisely the opposite effect-it deprives the factfinder of reliable and probative evidence. ${ }^{247}$ Thus, regarding reliability, implementation of Miranda's exclusionary rule entails both greater benefit and less cost than its Mapp counterpart.

Moreover, other factors that the Stone Court found to militate in favor of limiting collateral review of Mapp claims are not applicable to Miranda claims. The holding in Stone largely eliminates federal litigation of claims by state prisoners that their convictions rest on fourth amendment violations. ${ }^{248}$ The elimination of such litigation, the Stone Court believed, was beneficial in at least two respects. ${ }^{249}$ First, by removing a potential source of friction between the state and federal judiciaries, it positively affects state-federal relations. Second, it alleviates the workload of the federal judiciary. In contrast, however, extension of Stone's holding to Miranda claims, would accomplish neither objective, and might even produce opposite results. Habeas petitioners predictably would respond to a curtailment in the availability of habeas for raising Miranda claims by claiming that their confessions were involuntary. Consequently, federal courts would be required to return to the old due process standard with its case-by-case sifting of circumstances relevant to voluntariness. Given the uncertainty and unpredictability in such a case-bycase examination of circumstances, the friction consequent upon disagreements between federal and state courts would be unavoidable and significant.

Accordingly, it is by no means clear that prudence dictates extending Stone's holding to Miranda claims. It is similarly unclear whether its extension to Wade claims is justified. ${ }^{250}$ In sum, before undertaking to extend Stone's barrier to other claims based on prophylactic rules, the Court should (a)

245. Although an important, if not primary, objective of the Miranda decision was to ensure the voluntariness and reliability of custodial statements, its exclusionary rule is over-inclusive. That is, not all confessions obtained in violation of Miranda are either involuntary or unreliable. See generally Schulhofer, 79 Mich. L. Rev. 865, 890-91 (1981).

246. This statement is qualified, because not all evidentiary fruits of unreasonable searches or seizures are reliable and probative. For example, an out-of-court, eye-witness identification which grows out of an unconstitutional arrest may have been so suggestive as to be unreliable evidence. The essential point, however, is that it was not made so as a result of the fourth amendment violation.

247. See note 85 and accompanying text supra.

248. Habeas petitioners have unsuccessfully attempted to convert consent-to-search issues into Miranda claims. See, e.g., Smith v. Wainwright, 581 F.2d 1149, 1152 (5th Cir. 1978); United States ex rel. Carbone v. Manson, 447 F. Supp. 611, 617-18 (D. Conn. 1978).

249. See note 86 and accompanying text supra.

250. For example, Wade's requirement that counsel be present at post-indictment line-ups serves objectives similar to those of Miranda. The reliability of the trial process is improved by deterring the police from using suggestive identification procedures, and by facilitating effective defense cross-examination at trial. Wade also provides courts and law enforcement of ficials with an over-inclusive, bright-line rule to supplement an underlying due process right governed by a totality-of-the-circumstances test. See Stovall v. Denno, 388 U.S. 293 (1967). Accordingly, preclusion of habeas litigation of counsel claims under Wade would likely produce an increase in the number of due process claims in which petitioners assert that the police employed unnecessarily suggestive identification procedures conducive to irreparable misidentification. 
identify and weigh the costs and benefits of the particular rule at issue, (b) determine whether the precluded claim is readily transformable into another claim that would be cognizable on habeas corpus, and (c) weigh the relative costs and benefits of adjudicating the two types of claims.

\section{CONCLUSION}

Stone's limitation on federal collateral review of fourth amendment exclusionary rule claims reflects a utilitarian judgment concerning the comparative deterrent effectiveness of the exclusionary rule in various fora. Its premises are plausible: that exclusion of evidence seized in violation of the fourth amendment is not a personal constitutional right; that the exclusionary rule is a judicially created mechanism designed to deter fourth amendment violations generally; and that the deterrent benefits realizable from the rule's application in federal habeas corpus proceedings are outweighed by the attendant social costs. These premises provide theoretical underpinnings for the exception that permits habeas corpus litigation of a fourth amendment claim in the absence of an "opportunity for full and fair litigation" in the state courts. Although the intent of the exception is not entirely clear, it is best construed as enabling lower federal courts to ensure that the states and their courts take seriously their constitutional obligation to effectuate the fourth amendment rights of the people. Accordingly, the cognizability of fourth amendment exclusionary rule claims in federal habeas corpus actions should depend on whether the alleged error is likely to have an adverse impact on the effectuation of fourth amendment values. Finally, the doctrinal justification of Stone advanced here is consistent with the Court's subsequent refusal in Rose v. Mitchell to limit habeas corpus litigation of grand jury discrimination claims and provides a framework for determining whether judicial curtailment of habeas corpus litigation of other constitutional claims is authorized or prudent. 